\title{
Bloch, Gramsci e Paulo Freire: referências fundamentais para os atos da denúncia e do anúncio
}

\section{Bloch, Gramsci and Paulo Freire: fundamental references for the acts of denouncing and announcing}

\author{
Maria Ceci Araujo Misoczky ${ }^{1}$ \\ Joysi Moraes $^{2}$ \\ Rafael Kruter Flores ${ }^{3}$
}

\begin{abstract}
Resumo
A apropriação e aproximação das formulações de Ernst Bloch, Antonio Gramsci e Paulo Freire constituem parte importante das reflexões que compartilhamos em nosso coletivo de trabalho, que tem como tema de estudo organização e práxis libertadora. Neste artigo fazemos uma apresentação de nossas leituras situadas destes autores, seguida de um exercício de aproximação entre suas formulações. A realidade como processo histórico e a libertação do ser humano das condições de opressão (materiais e intelectuais) estão presentes nas obras dos três autores. Para Freire a libertação do oprimido é também a libertação do opressor; para Gramsci os subalternos devem tornar-se hegemônicos pela concepção de uma nova direção intelectual e moral que seja comprometida com o mais alto valor do ser humano: a própria existência; para Bloch a libertação é imanente à existência humana. Por conseguinte, a libertação também é concebida pelos três autores como um processo, da mesma forma que a hegemonia, que nunca é total, fixa ou definitiva, ou a realidade que está sendo o tempo todo. Bloch, Gramsci e Freire autorizam posições que vinculam a crítica ao sistema com a utopia presente e concreta, em nossa aprendizagem na interação com os movimentos e lutadores sociais.
\end{abstract}

Palavras-chave: organização; libertação; esperança; lutas sociais.

\begin{abstract}
The appropriation and relations of Ernst Bloch, Antonio Gramsci and Paulo Freire's texts is an important part of the reflections shared in our collective work, which has as study subject organization and the praxis of liberation. In this article we present our situated readings of these authors, followed by an exercise of building relations among them. Reality as a historical process and the liberation of human beings from oppressive conditions (material and intellectual) are present in the writings of these three authors. For Freire, the liberation of the oppressed is also the liberation of the oppressor; for Gramsci, the subalterns should become hegemonic by the formulation of a new intellectual and moral direction which should be committed to the higher values of human kind: its existence; for Bloch, liberation is immanent to the human existence. Therefore, liberation is conceived by these authors as a process, the same stands for hegemony, which is never complete, fixed or definitive, or to reality, which is becoming all the time. Bloch, Gramsci and Freire authorize positions which connect the system critique with the present and concrete utopia, in our learning in the interaction with social movements and struggles.
\end{abstract}

Keywords: organization; liberation; hope; social struggles.

${ }_{1}$ Doutora em Administração pela Universidade Federal do Rio Grande do Sul. Docente da Escola de Administração da Universidade Federal do Rio Grande do Sul - PPGA/UFRGS. Coordenadora do Grupo de Pesquisa Organização e Práxis Libertadora. Endereço: Escola de Administração/UFRGS - Av. Washington Luis 855 - Porto alegre/Rio Grande do Sul - Brasil - CEP: 90010-460 - E-mail: mcamisoczky@ea.ufrgs.br

2 Doutora em Administração pela Universidade Federal do Rio Grande do Sul - UFRGS - UFRGS. Professora Adjunta da Universidade Federal Fluminense. Pesquisadora do Grupo de Pesquisa Organização e Práxis Libertadora. Endereço: Faculdade de Administração e Ciências Contábeis - $7^{\circ}$ andar-Campus do Valonguinho - Centro - Niterói - RJ - Brasil - CEP 24020-150. E-mail: joysimoraes@yahoo.com.br

3 Mestre em Administração/Organizações. Doutorando no Programa de Pós-Graduação em Administração- Universidade Federal do Rio Grande do Sul UFRGS. Pesquisador do Grupo de Pesquisa Organização e Práxis Libertadora. Endereço: Fernandes Vieira, 533/203 - Bom Fim - - Porto Alegre/Rio Grande do Sul - Brasil - CEP: 90035091. Email: rkflores@ea.ufrgs.br 


\section{Introdução}

Neste artigo* explicitamos e compartilhamos as referências fundamentais de nosso coletivo de trabalho, que tem como tema de estudo organização e práxis libertadora.

Estes não são, porém, os únicos autores com os quais trabalhamos. A atividade teórica em que estamos imersos - e que se orienta por um princípio ético-material definido a partir da vida como critério de verdade - leva-nos a buscar diálogos e interfaces com diversos autores, especialmente, com aqueles que realizam seu fazer acadêmico em intensa articulação com a organização das lutas sociais. Estamos convencidos de que o processo coletivo de construção de aportes teóricos que contribuam para a práxis da libertação inclui dialogar com experiências significativas de organização popular e com as representações teóricas com as quais encontram correspondência. Aí se encontram releituras da tradição marxista e reinvenções do patrimônio humanista, resguardando o que Quijano (2001) chama de reoriginalização cultural a partir de nossa situação geopolítica latino-americana e brasileira.

Trabalhamos em uma escola de administração e estamos inseridos na área disciplinar dos estudos organizacionais (EOs). Nessa área existe uma vertente que se apresenta como estudos críticos em administração, qualificada, em um artigo do qual uma de nós foi coautora, como produtora de uma crítica domesticada que se mantém dentro dos limites da gestão e se propõe a, no máximo, produzir microemancipações que não coloquem em risco a ordem do capital (MISOCZKY; AMANTINO-DEANDRADE, 2005).

No Brasil, pelo menos, desde os estudos e a militância de Tragtenberg $(2004,2005,2006)$, há uma importante contribuição em torno do tema da organização dos trabalhadores e da participação na gestão do processo de produção. É importante destacar, na atualidade e entre outros, o grupo de pesquisa coordenado por José Henrique Faria sobre economia do poder. ${ }^{4}$ No entanto, o tema das organizações de resistência e luta social tem estado praticamente ausente dos EOs; não apenas no contexto nacional. Em decorrência disso, há um grande estranhamento em nossa área acadêmica quanto ao tema dos movimentos sociais e, mais ainda, em relação ao tema das lutas anticapitalistas. Com frequência nos deparamos com uma posição síntese: este não é um tema dos estudos organizacionais. Claro que tal declaração, vinda do mainstream dos EOs, toma como referência outro mainstream: o dos estudos de movimentos sociais e sua correspondente teorização, uma subdisciplina institucionalizada, com características predominantemente descritivas e analíticas, muito distanciada dos próprios movimentos $^{5}$ (COX; FOMINAYA, 2009).

No entanto, não é novo o caminho a que nos propusemos percorrer, focado na construção de aportes que contribuam para as lutas sociais e que articulem de modo coerente projetos políticos e a organização como meio para sua efetivação. É importante recordar, pelo menos, a preocupação de Luxemburgo (2005), para quem não havia uma única forma de organização dos trabalhadores (o partido); para quem a luta de classes, como processo incessante, leva a contínuas modificações das formas organizacionais. Rosa Luxemburgo valorizava as experiências produzidas em circunstâncias onde se colocam exigências que solicitam soluções imediatas. Dizia ela que nesse processo dialético as massas inconscientes se elevam à consciência. É nesse processo que se

\footnotetext{
* Agradecemos a leitura atenta, as críticas e contribuições de Sueli Goulart. A convivência com Sueli, no espaço da Escola de Administração, do PPGA e do Grupo de Pesquisa Organização e Práxis Libertadora, tem sido muito importante para a qualificação do nosso trabalho.

${ }^{4}$ A esse respeito, ver os três volumes de FARIA (2004).

${ }^{5}$ Em decorrência dessa declaração reiterada, consideramos importante formalizar um ajuste de contas com as teorias predominantes no estudo de movimentos sociais (MISOCZKY; FLORES; GOULART, 2008). Ao fazê-lo, constatamos que a teoria de movimentos sociais (MSs) é extremamente influenciada pelos estudos organizacionais. Aliás, no período recente, estudiosos de organizações também do contexto norte-americano têm, explicitamente, dialogado e compartilhado referenciais com a teoria de MSs, em busca de inspiração para tratar de fenômenos empresariais contemporâneos. Naquele artigo realizamos, então, uma revisão dessa trajetória de aproximações, com foco na teoria da mobilização de recursos, na teoria da estrutura de oportunidades políticas e no esforço de convergência entre as mesmas, bem como na aproximação recente entre a teoria de movimentos sociais e a teoria institucional e, também, na abordagem de redes. Orientamos nossa reflexão pela pergunta sobre as consequências que uma teoria extremamente influenciada pela lógica empresarial pode ter para nossa compreensão de movimentos que se orientam para a superação dessa lógica e das relações sociais por ela constituídas.
} 
produzem respostas inesperadas; é nele que a criação se impõe em oposição ao codificado, ao rígido e burocrático (LOUREIRO, 2005).

Para Rosa Luxemburgo, não pode haver separação entre o elemento espontâneo e o consciente. A organização e as tarefas a realizar se formam no decorrer da própria luta; não, previamente. As organizações são, nesse sentido, "muito mais resultado da ação das massas que condições prévias para a existência de qualquer política revolucionária" (LOUREIRO, 2005, p.32). O que Rosa nega é o fetichismo da organização e o que enfatiza é a importância da experiência. "Organização, esclarecimento e luta não são aqui separados, mecânica e temporalmente distintos [...], são apenas diferentes aspectos do mesmo processo" (LUXEMBURGO, 2005, p.49).

Compartilhando esse ponto de vista, nossa proposta é contribuir para a reflexão sobre a organização das lutas sociais, ao mesmo tempo em que escolhemos nos manter na área disciplinar dos EOs. Entendemos que travar a luta cultural no âmbito de uma disciplina que nasce no mercado e para o mercado, e que tem na sua origem e como razão de ser a produção de conhecimento para aperfeiçoar a gestão a serviço do capital, é uma práxis acadêmica relevante porque problematiza a concepção hegemônica de organização (sinônimo de empresa). Em uma conjuntura em que o discurso gerencialista é dominante e se expande para todas as esferas da vida associada, é importante construir conhecimento contra-hegemônico no próprio espaço em que o discurso gerencialista é produzido e reproduzido.

Para fazê-lo, tem sido preciso exercitar a construção do conceito de organização. A aplicação irrefletida do conceito hegemônico de organização, certamente, levar-nos-ia à impossibilidade de reconhecer os fenômenos sociais nos quais estamos interessados. Negamos que os conceitos sejam fixos e a-históricos. Pelo contrário, os conceitos são históricos e transitórios, tal como a realidade que queremos expressar através deles. Além disso, alguns conceitos são antecipadores, são expressões de uma realidade ainda-não- existente. Se não for assim, estaremos meramente reproduzindo o que já está concluído, sem condições de tratar as coisas presentes em sua conexão com o futuro, impossibilitados de sermos ativos e solidários com o "bem que vem abrindo caminho" (BLOCH, 2005, p.196).

A problematização do conceito de organização $^{6}$ não tem sido feita, de forma alguma, no isolamento da academia. Uma importante referência em nosso trabalho é reconhecer e valorizar o conhecimento que os movimentos produzem desde baixo; sejam informações sobre a sociedade, sejam reflexões sobre seus processos de organização e luta. Essa constatação já se encontrava em Eyerman e Jamison (1991), para quem os movimentos geram conhecimento a partir de seus próprios recursos ou em aliança com tradições intelectuais estabelecidas. Nesse sentido, orientamos nosso fazer acadêmico pela intensa proximidade com as lutas sociais: essa proximidade se expressa em diferentes estudos com diferentes intensidades - algumas vezes, somos simultaneamente ativistas e acadêmicos; em outras, atuamos como observadores participantes em solidária convivência.

Finalmente, falta dizer que nos orientamos por um princípio ético-material definido a partir da vida como critério de verdade. Nas palavras de seu formulador, Dussel (2001, p.74): "tudo o que funcione eticamente deve produzir, reproduzir e desenvolver a vida humana em comunidade, e, em último caso, a vida de toda a humanidade."

Nos itens que seguem fazemos uma apresentação de nossas leituras situadas de Bloch, Gramsci e Freire, seguida de um exercício de aproximação, fundamentais para a compreensão da organização como meio e aprendizagem para a práxis da libertação e, portanto, para o estudo da organização das lutas sociais.

\section{Ernst Bloch: a utopla concreta do não-ainda}

Münster (1993, p.20) considera a obra de Bloch fundadora de uma "filosofia neomarxista do futuro", como "um pensamento que se define a si mesmo como 'ciência marxista das tendências', indicando as possibilidades

\footnotetext{
${ }^{6}$ Voltaremos a esse tema no encerramento deste artigo.
} 
de transformação inerentes ao ser econômico, político e social". Na interpretação de Dussel (2002, p.457), Bloch desenvolve, durante toda sua vida, "o momento crítico positivo do projeto de libertação", o "momento positivo do projetar (como afeto e razão), as alternativas possíveis ainda-não-realizadas". Bloch expandiu o conceito de utopia, retendo a usual associação com o bem, mas questionando a distinção entre utopia e realidade (ANDERSON, 2006). Em Bloch (2005), a utopia passa a ser um topos da atividade humana orientada para o futuro, um topos da consciência e a força ativa que impulsiona para o que ainda-não-é.

O prefácio do primeiro volume de $O$ princípio esperança (BLOCH, 2005, p.13-14) começa com as perguntas fundamentais: "Quem somos? De onde viemos? Para onde vamos? Que esperamos? O que nos espera?" Indica, logo a seguir, que o que importa é "aprender a esperar"; não esperar com resignação, mas efetuar um ato de esperar que é "apaixonado pelo êxito em lugar do fracasso", um esperar que não é passivo, um esperar que "requer pessoas que se lancem ativamente naquilo que vai se tornando e do qual elas próprias fazem parte"; um esperar que "não permite conformar-se com o precário que aí está, não permite a resignação". Para que esse esperar ativo e positivo se realize é preciso transpor: "pensar significa transpor". Pensar "de tal maneira que aquilo que está aí não seja ocultado nem omitido"; que a transposição não se dê "na direção de um mero vazio de algum diante-de-nós, no mero entusiasmo, apenas imaginado abstratamente", mas "capte o novo como algo mediado pelo existente em movimento, ainda que, para ser trazido à luz, exija ao extremo a vontade que se dirige para ela. A transposição efetiva conhece e ativa a tendência do curso dialético instalado na história”. Isto é, a esperança, ainda que seja um princípio subjetivo, é fundada na práxis histórica, pois são as condições sociais que indicam o futuro, a partir da análise do presente e do passado.

Esse marxismo fundado na esperança materialista e dialética precisa ser entendido como crítica ao marxismo mecanicista e esquemático que degradava a imaginação revolucionária, ao marxismo degenerado em dogma cientificista (RAULET, 1982). É a partir desse marxismo que Bloch foi acusado de metafórico, ambíguo, idealista. Dussel (2002) ressalta, no entanto, que a posição utópica proposta por Bloch seria incompreensível se não partisse do conteúdo radical e material da vida.

A esperança concreta tem suas raízes antropológicas precisamente na demanda mais urgente - a fome - e na pulsão básica mais confiável - a autopreservação. A fome é a incitação somática mais rápida. É o fator ônticoexistencial de um impulso elementar que tem origem e fundamento em um estágio de insatisfação que leva à apropriação de um ainda-não que se manifesta, nesse nível, como um não-ter. O ímpeto - o appetitus e seu desejo - irrompe frontalmente nos afetos expectantes - como angústia, medo, esperança e fé - que possuem uma intenção passional de longo alcance. No entanto, é somente a esperança, o afeto expectante contrário à angústia e ao medo, que tem como referência o horizonte mais amplo e mais claro, o impulso para a frente.

É exatamente nesse ponto que se forma aquilo que aviva o aspecto desejante ${ }^{7}$ nos afetos expectantes que sempre se originam da fome, desejante esse que ocasionalmente distrai e amolece, mas ocasionalmente também ativa e se estende até o alvo de uma vida melhor: formam-se sonhos diurnos. (BLOCH, 2005, p.79)

Eles sempre procedem de uma carência e querem se desfazer dela. Todos eles são sonhos de uma vida melhor. Sem dúvida, há entre eles sonhos escapistas, baixos, de todo, como se sabe. [...] Mas quantos outros sonhos diurnos ideais conservam a coragem e a esperança dos seres humanos, não desviando os olhos do real, mas, ao contrário, encarando a sua evolução e o seu horizonte. Quantos reforçaram, pela via da antecipação, do sobrepujamento e de suas imagens, a vontade de não renunciar.

[...] o sonho diurno desenha no ar receptíveis vultos de livre escolha, e pode se entusiasmar e delirar, mas também ponderar e planejar. [...] O sonho diurno pode proporcionar ideias que não pedem interpretação, e sim elaboração. (Ibidem, p.79 e 88)

O sonho diurno abrange o sonho desperto, do tipo cômodo, trivial, despropositado e paralisante, até o tipo responsável, engajado, a fim de que a antevisão venha a ser concretizada. O sonho diurno tem as seguintes

${ }^{7} \mathrm{~A}$ partir daqui, todos os registros em itálico são do próprio Bloch. 
características (BLOCH, 2005): (1) não ser opressivo; "a casa do sonho desperto só é mobiliada com representações auto-escolhidas" (Ibidem, p.90); (2) o eu permanece intacto no contexto de sua vida e de seu mundo acordado, não foi destituído por nenhum tipo de "censura imposta por um ego moral". Seu "ego utopicamente sobreexaltado edifica a si mesmo e seu castelo no ar em um azul muitas vezes surpreendentemente leve" (Ibidem, p.92); (3) o ego de quem devaneia pode se reportar aos demais, pode incluir a amplitude humana e assumir uma dimensão utópica que "coloca o mundo melhor igualmente como o mais bonito, em imagens mais completas, como a Terra não as comporta ainda" (Ibidem, p.96). É antes de tudo o "interesse revolucionário, com seu conhecimento de como está ruim o mundo e seu reconhecimento do quanto ele poderia ser bom como um outro mundo, que necessita do sonho desperto da melhoria do mundo" (Ibidem, p.97); (4) a fantasia diurna tem os desejos como ponto de partida, mas vai com eles até o fim; "quer chegar ao lugar de sua realização" (Ibidem, p.97).

Nos afetos expectantes negativos - angústia, medo e desespero - os sonhos diurnos giram em torno do infernal. Já nos afetos expectantes positivos - esperança e confiança - os sonhos diurnos frustram o medo e afogam a angústia. A esperança, ainda que permaneça aberta quanto ao final, possui uma incerteza diferente da do medo, não passiva. A esperança é um afeto prático, militante. Quando da esperança surge a confiança, anula-se a expectativa. Por isso, apenas a esperança tem uma função utópica, tanto no afeto quanto na imaginação e na ideia (BLOCH, 2005).

Para avançar na direção da utopia concreta, Bloch (2005, p.117) parte das formulações de Freud e reflete sobre a natureza da pré-consciência, afirmada como a localização onde o consciente para de repercutir, onde o vivenciado submerge, onde alvorece algo até ali não consciente. A pré-consciência não se refere ao reprimido, mas a algo que está em ascensão: no sonho diurno revela-se "uma determinação importante do ainda-nãoconsciente". Esse é tão pré-consciente quanto o inconsciente da repressão ou do esquecimento, mas não está subordinado à consciência atual, manifesta, e sim "a uma forma de consciência futura, que apenas está surgindo" - é o local psíquico de nascimento do novo, é o espírito do sonho para a frente. Seus momentos privilegiados são a juventude, as épocas prestes a dar uma guinada, a produção criativa. Com relação a todos eles, é usual que se contraponha a resistência da receptividade, a "receptividade do mundo embotado", que recusa o que não se encaixa no habitual. No ainda-não-consciente, no ainda-não-sendo, o que dá trabalho não é o reprimido, mas a dificuldade do caminho. $O$ bloqueio atuante, que se apresenta sempre como bloqueio histórico e social, fundamenta-se no estranhamento e na recusa ao objeto que ainda não veio a ser. Para enfrentá-lo, é necessário um conhecimento que contribua para esse devir, que escave o que houve, mas também o que haverá.

A nossa época é a primeira a possuir os pressupostos socioeconômicos para uma teoria do ainda-nãoconsciente e do que está relacionado a ele no que-ainda-não-veio-a-ser-no-mundo. O marxismo, sobretudo, foi o pioneiro em proporcionar ao mundo um conceito de saber que não tem mais como referência essencial aquilo que foi ou existiu, mas a tendência do que é ascendente. Ele introduz o futuro na nossa abordagem teórica e prática da realidade. Esse conhecimento da tendência é necessário para rememorar, interpretar e revelar as mensagens que até o não-mais-consciente e o existente podem continuar nos enviando, além de ser necessário para reafirmar sua eterna vigência. Dessa maneira, o marxismo resgatou o núcleo racional da utopia e o da dialética da tendência, ainda de cunho idealista, trazendo-os para o concreto. (BLOCH, 2005, p.141)

O olhar para frente que Bloch (2005, p.143) tem em mente é seletivo e não turvado; exige uma intuição saudável e não apática, uma intuição predisposta a se tornar consciente. Essa intuição produtiva é consciente de si como um ainda-não-consciente que demonstra sua vontade de aprender, a "capacidade de ver ao seu redor por meio de uma previsão, de conjugar um olhar abrangente e uma prudência na sua previsão". Nesse olhar que se torna mais aguçado ao se tornar consciente, o "sonho quer ser plenamente claro; a intuição correta, evidente".

Só quando a razão toma a palavra, a esperança, na qual não há falsidade, recomeça a florescer. $O$ próprio ainda-não-consciente deve se tornar consciente quanto ao seu ato; consciente de que é uma 
emergência e ciente quanto ao conteúdo, ciente de que está emergindo. Chega-se assim ao ponto em que a esperança, esse autêntico afeto expectante no sonho para a frente, não surge mais como uma mera emoção autônoma, [...] mas de modo consciente-ciente como função utópica. [...] $O$ que distingue a fantasia da função utópica da mera fantasia quimérica é o fato de apenas a primeira ter a seu favor um ainda-não-ser do tipo que pode ser esperado, isto é, que não gira nem se perde em torno de uma possibilidade vazia, mas antecipa psiquicamente um possível real. (BLOCH, 2005, p.144)

Bloch (2005, p.145-146) esclarece que a luta contra o imaturo e o abstrato na função utópica nada tem a ver com o realismo do burguês ou com o pragmatismo. O olhar cheio de esperança e fantasia da função utópica só pode ser corrigido a partir do real da própria antecipação; ou seja, a partir de um realismo que "o é somente porque versado na tendência do real, na possibilidade real-objetiva à qual a tendência está associada". Aqui, tem lugar o conceito de utópico-concreto como expressão de uma capacidade utópica "colocada sobre os próprios pés", "consciente-ciente da intenção expectante" cuja "ratio é a razão não debilitada de um otimismo militante". "O conteúdo ativo da esperança", conscientemente esclarecido e cientemente explicado, "é a função utópica positiva".

De modo diferente das utopias abstratas, preenchidas essencialmente com ideais, a utopia concreta conecta os ideais ao processo do mundo.

Nas suas antecipações, caso sejam concretas, o ideal tem um correlato nos conteúdos objetivos da esperança, os da tendência latência. Esse correlato possibilita ideais éticos como exemplos e estéticos como pré-aparências, indicando para algo que possivelmente pode se tornar real. (BLOCH, 2005, p. 172)

Então, sendo "variações do conteúdo básico que é o bem supremo", os ideais se comportam em relação a esse conteúdo maior da esperança, a "esse conteúdo possível do mundo, como meios para um fim". A liberdade da função utópica

tem a sua atividade e o seu próprio ideal no propósito de dar um significado objetal e liberar o ser ideal (bem supremo) que ainda não veio a ser, mas que se desenvolve como possibilidade real nas auroras, na linha de frente do processo do mundo. (BLOCH, 2005, p. 173)

Nas formulações de Bloch (2005, p.194) esse "imaginar-se rumando para o melhor" ocorre, primeiro, apenas interiormente: "o ser humano fabula desejos". Entretanto, nada circula interiormente se o exterior for estanque, se a vida do lado de fora não for tão inconclusa como a do eu, se o mundo estivesse encerrado em fatos fixos e consumados. Em vez disso, existem apenas processos: relações dinâmicas nas quais o "existente dado ainda não é completamente vitorioso".

O real é processo, e processo é a mediação vastamente ramificada entre o presente, o passado pendente e, sobretudo, o futuro possível. No seu front processual, todo real passa a ser o possivel e todo possível é primeiramente parcial-condicionado, sendo ele o determinado que ainda não está completo ou concluído. (BLOCH, 2005, p. 194)

Nesse ponto, Bloch (2005) distingue entre o cognitiva ou objetivamente possível e o possível-real. Objetivamente possível é tudo aquilo cuja ocorrência pode ser cientificamente esperada ou que não pode ser excluída com base no conhecimento disponível. Realmente possível

é tudo aquilo cujas condições ainda não estão integralmente reunidas na esfera do próprio objeto, seja porque elas ainda estão amadurecendo, seja, sobretudo, porque novas condições - ainda que mediadas pelas existentes - concorrem para a ocorrência de um novo real. (BLOCH, 2005, p. 195)

O ser em movimento, que vai se modificando, que pode ser modificado, assim como se apresenta em termos dialético-materiais, tem esse poder-vir-a-ser inconcluso, esse ainda-não-estar-concluído, tanto na sua base quanto no seu horizonte. De modo que a partir daí pode ser afirmado que o realmente possível da novidade suficientemente mediada, ou seja, mediada em termos dialético-materialistas, 
confere à fantasia utópica o correlato concreto situado fora de um mero fermentar, de uma mera efervescência no círculo interior da consciência. [Exatamente] a utopia concreta tem na realidade do processo um correspondente: o do novum mediado. Somente essa realidade do processo, e não uma faticidade absolutizada e reificada, arrancada de dentro da realidade, pode formular um juízo a respeito dos sonhos utópicos ou rebaixá-los a meras ilusões. [...]

Portanto, chegou a hora de um novo conceito de realidade, diferente do conceito tacanho e enrijecido da segunda metade do século XIX, diferente do conceito do positivismo avesso ao processo e também do seu correspondente: o mundo ideal descompromissado da pura aparência. (BLOCH, 2005, p.195)

Por isso e para isso, o saber precisa deixar a forma contemplativa, precisa deixar de meramente se referir ao que já está concluído e já passou, precisa de meios para tratar com as coisas presentes e deixar de ser cego para o futuro. Esse outro modo do saber tem a capacidade de acompanhar o processo, de ser ativo e partidário do "bem que vem abrindo caminho", do que "é digno do ser humano no processo". Para Bloch (2005, p.196), essa forma de saber é a única objetiva, a única que produz o real na história: "os acontecimentos produzidos por seres humanos que trabalham dentro do rico tecido processual entre passado, presente e futuro". Além disto, esse tipo de saber conclama os sujeitos da própria produção consciente. Ele não cultiva "o otimismo banal e automático do progresso em si, que é apenas uma reprise do quietismo contemplativo", que "traveste o futuro de passado", porque olha para o futuro como algo há muito concluído.

Assim, o novo fica de fora da compreensão; o presente constitui um embaraço. Bloch (2005, p.279) relaciona esse modo de saber com o pensamento na forma de mercadoria e com a decorrente intensificação do sentimento de impotência: "o fato de todos os homens e todas as coisas se tornarem mercadoria não lhes proporciona apenas alienação, mas deixa claro que a forma de pensamento 'mercadoria' é ela própria, a forma de pensamento". Em consequência, esquece, em vista do produto reificado, o producente, o que está aberto diante de nós. Já o marxismo, ciência do acontecimento e da transformação contínuos, ciência tendencial histórico-dialética, permite, sempre tendo como propósito a ação, apreender a possibilidade real-objetiva de futuro que está contida na realidade do presente, mediada pelo passado. É desse modo que, tendo o futuro como horizonte e o passado como átrio, o marxismo confere à realidade a sua dimensão real. É a partir de Marx que se explicitam a "inserção da mais audaz intenção no mundo que acontece, a unidade da esperança e da noção de processo, enfim, o realismo" (BLOCH, 2006, p.177).

Não se trata, portanto, do pessimismo absolutizado do saber do "antiquário contemplativo". Não se trata, também, de qualquer otimismo automático. Em lugar desses, coloca-se, como associada ao saber da decisão e à decisão do saber obtido, a utopia concreta, a ação concretamente mediada, o otimismo militante. Por meio dele, e Bloch (2005, p.197) recorre novamente a Marx, "não são realizados ideais abstratos, mas certamente são liberados os elementos reprimidos da sociedade nova, humanizada, ou seja, do ideal concreto". O "otimismo bem fundado" está em paz com o processo, corrige o imobilismo fatalista. Sua filosofia é a esperança concebida em termos materialistas. Meyer (2008) chama a atenção para a relação intrínseca entre essa filosofia baseada na esperança e a práxis: a esperança não pode ser considerada como tal se não for acompanhada de uma práxis que a efetive. A esperança, sem práxis, é apenas um pensamento ficcional e vazio, que acaba deixando de ser esperança. A práxis é, portanto, indispensável para a esperança, sem a qual esta deixa de existir.

A caminhada para o novo requer proceder passo a passo, já que nem tudo é possível e executável a qualquer momento; sendo o possível definido como tudo aquilo que encontra as condições dadas em proporção suficiente à sua realização. Nesses termos, tudo aquilo que ainda não encontra as condições necessárias é faticamente impossível; e a imagem-alvo se mostra objetiva e subjetivamente uma ilusão. A saída dessa armadilha reside na teoria-práxis concreta, em sua estreita ligação com a construção da possibilidade realobjetiva.

Tanto a preocupação crítica que determina a velocidade da caminhada, quanto a bem fundada expectativa que garante um otimismo militante em direção ao alvo, são definidas pela noção obtida do correlato da possibilidade. (BLOCH, 2005, p. 204) 
Esse correlato tem dois lados: um reverso, no qual se encontram as "medidas do possível em cada caso", e um anverso, no qual "o totum derradeiramente possível se caracteriza como ainda aberto". O primeiro ensina o comportamento a ser adotado na caminhada para o alvo; o segundo impede que êxitos parciais nessa caminhada sejam tomados como um todo e o encubram. Esse correlato de duas faces é a própria matéria dialética: "possibilidade real é apenas a expressão lógica para a condicionalidade material do tipo suficiente por um lado e abertura material (inesgotabilidade do útero da matéria) por outro". Esse correlato, por um lado, ilumina a teoria-práxis revolucionária com a "consideração crítica do atingível, da expectativa bem fundada da própria alcançabilidade no interior do correlato mais abrangente da possibilidade real", com "suas determinações críticas e impreteríveis" que exigem análise fria e estratégia precisa - o vermelho frio; por outro, ilumina a teoria-práxis revolucionária com o entusiasmo da "inexaurida plenitude da expectativa" - o vermelho quente (BLOCH, 2005, p.204 e 206).

Esses dois modos de ser da cor vermelha andam sempre juntos, embora sejam distintos: o ato analíticosituacional do marxismo está entrelaçado com o ato prospectivo-entusiástico no método dialético. Sem o horizonte do limitadamente possível se cairia em um entusiasmo totalmente desmedido, do tipo abstratamente utópico. Assim, a investigação das "perspectivas do sendo-em-possibilidade se dirige para o horizonte em termos de uma amplidão desobstruída, incomensurável, em termos do possível ainda não esgotado e ainda não realizado". Sem esse aquecimento da análise das condições históricas e das condições práticas atuais, a história sucumbe ao economicismo e ao oportunismo. Portanto, somente juntos "o frio e o calor da antecipação evitam que o caminho em si e o alvo em si sejam mantidos afastados um do outro de modo não dialético, evitam seu isolamento e reificação". Quem realiza a análise das condições na totalidade do situacional-histórico e atua desmascarando as ideologias e desencantando a aura metafísica é a corrente fria do marxismo; ela faz do marxismo uma ciência das condições e uma ciência de luta e oposição aos entraves e dissimulações ideológicas. Já da corrente quente do marxismo fazem parte "a intenção libertadora e a tendência real humanomaterialista, materialista-humana, e é em função de seu alvo que todos esses desencantamentos são empreendidos". O marxismo, como doutrina do calor, "se refere unicamente ao ser-em-possibilidade positivo, não sujeito a qualquer desencantamento, que abrange a realização progressiva do que está sendo realizado, primeiramente no entorno humano", e que, nesse entorno, denota o totum utópico, "justamente aquela liberdade, aquela pátria da identidade em que o ser humano não se comporta em relação ao mundo, nem o mundo em relação ao ser humano como estranhos" (BLOCH, 2005, p.206-207).

O caráter utópico dessa teoria-práxis se expressa no poder-ser em seu desafio ao formalmente permitido, ao objetivamente presumível, ao aberto conforme o objeto. No entanto, a sua possibilidade real comporta uma condicionalidade parcial-real do objeto. "O realmente possível principia com o germe em que foi disposto o vindouro." O que nele está pré-formado procura desdobrar-se: todavia, "não como se anteriormente já existisse"; ao contrário, ele "preserva a sua abertura como desdobramento".

O possível real, como disposição para o real, não só mantém esta em movimento, mas comporta-se também de modo essencial em relação à realidade já existente, sendo o totum definitivo dessa disposição que continuará a desenvolver-se cada vez mais. (BLOCH, 2005, p.235)

Portanto, não haveria nenhum ainda-não-existe, nem haveria nenhuma coisa que ainda-não-está-consciente, se esses ainda-não não pudessem se mover no possível e voltar-se ao seu caráter aberto.

Transformação do mundo transformável é a teoria-práxis do possível real realizável na linha de frente do mundo, do processo do mundo. E nessa ponta, o possível real, apátrida em qualquer filosofia estático-contemplativa, constitui-se no problema real do mundo como tal: ele é o idêntico ainda não corrido da manifestação e do ente real, enfim, da existência e da essência contidas nele. (BLOCH, 2005, p.243)

O possível é, portanto, o não totalmente condicionado, o não-consumado, a terra do futuro, o mundo inconcluso; ainda que e sempre pleno de mediações tendenciais-históricas. O futuro do tempo é precisamente o espaço das possibilidades reais da história, situando-se no nível teórico-prático da linha de frente do processo do mundo, onde são tomadas as decisões e se descortinam novos horizontes. Esse processo em direção ao 
futuro é unicamente o processo da matéria, onde seres humanos e coisas estão unidos. O homem e seu trabalho, na condição de elementos decisivos no processo histórico do mundo, constituem um fator subjetivo - a potência não encerrada de mudar as coisas, e um fator objetivo - a potencialidade não encerrada da mutabilidade, da alteridade do mundo. A potência subjetiva é o elemento transformador e realizador na história; a potência objetiva coincide não só com o transformável, mas também com o realizável na história. É o ser humano como realizador que condensa essas potências e as transforma em matéria em processo. Essa é a concepção, segundo Bloch (2005), de um materialismo para adiante, segundo o qual as coisas só sucedem no próprio agora porque sucedem na nascente de tudo.

\section{Antonio Gramsci: hegemonia, consciêncla e modos de vida}

Ativista político e intelectual, Gramsci produziu uma obra voltada para a superação da pobreza material, intelectual e moral do ser humano.

Quanto mais um indivíduo é obrigado a defender a própria existência física imediata, tanto mais afirma e se coloca do ponto de vista de todos os complexos e mais elevados valores da civilização e da humanidade. (GRAMSCI, 2002a, p.34)

Em Gramsci é impossível separar a filosofia "científica" da filosofia "vulgar" e popular. A filosofia é a crítica e a superação da religião e do senso comum, que não constituem uma ordem intelectual, já que não possuem uma unidade coerente. A filosofia produz coerência. Por isso mesmo, toda filosofia tende a se tornar senso comum. O que distingue a filosofia da práxis é que esta objetiva tornar-se um senso comum "renovado com a coerência e o vigor das filosofias individuais", que são organicamente ligadas à vida prática.

A filosofia da práxis não busca manter os "simples" na sua filosofia primitiva do senso comum, mas busca, ao contrário, conduzi-los a uma concepção de vida superior. Se ela afirma a exigência do contato entre os intelectuais e os simples, não é para limitar a atividade científica e para manter uma unidade no nivel inferior das massas, mas, justamente, para forjar um bloco intelectual-moral que torne politicamente possível um progresso intelectual de massa e não apenas de pequenos grupos intelectuais. (GRAMSCI, 2006a, p. 103)

Para Gramsci (2006a), todos exercem atividade intelectual, inclusive, o operário, por mais simples que seja sua atividade. Não existe trabalho puramente físico, existem gradações de funções com mais ou menos atividades físicas e intelectuais. Além disso, fora de suas funções profissionais, os homens são artistas, possuem gostos particulares, possuem condutas morais, contribuem para modificar ou conservar uma visão de mundo: exercem atividades intelectuais.

Essa noção de intelectuais em Gramsci (2006b) difere da noção corrente de intelectuais. Para o autor, há um erro metodológico que impede a distinção entre as atividades dos intelectuais das atividades dos demais grupos. $\mathrm{O}$ erro reside em tomar como critério de distinção aquilo que é intrínseco às atividades intelectuais segundo uma concepção hierárquica da produção de conhecimento. Em vez disso, para Gramsci, só se pode compreender as atividades intelectuais considerando o sistema de relações sociais em que essas atividades ocorrem. Assim, o que faz de um homem um intelectual não é a sua própria atividade intelectual, que todos exercem, mas as relações que o colocam na função de intelectual em determinada sociedade. O mesmo ocorre com outras funções: o que caracteriza a atividade do operário não são suas atividades físicas e técnicas específicas, mas o seu trabalho em determinadas condições e relações sociais; o que caracteriza a atividade do empresário não são os conhecimentos que ela exige, o que o caracteriza como empresário são as relações sociais nas quais se encontra. Esse mesmo critério de distinção é o que permite distinguir entre intelectuais orgânicos e intelectuais tradicionais.

A relação da atividade do intelectual orgânico com a atividade econômica do grupo ao qual pertence é "orgânica" no sentido de que a existência de uma pressupõe a existência da outra. Não existem atividades econômicas sem atividades intelectuais que lhes permitam um mínimo de coerência e consciência. 
Todo grupo social, nascendo no terreno originário de uma função essencial no mundo da produção econômica, cria para si, ao mesmo tempo, organicamente, uma ou mais camadas de intelectuais que lhe dão homogeneidade e consciência da própria função, não apenas no campo econômico, mas também no social e político: o empresário capitalista cria consigo o técnico da indústria, o cientista da economia política, o organizador de uma nova cultura, de um novo direito etc. (GRAMSCI, 2006b, p.15)

Os intelectuais orgânicos emergem das classes a partir de suas funções econômicas como "especializações de aspectos parciais da atividade primitiva do tipo social novo que a nova classe deu à luz" (GRAMSCI, 2006b, p.16); ou seja, a atividade de um intelectual é intrínseca à atividade econômica de sua classe. A única diferença entre o intelectual orgânico e os demais membros do seu grupo é que sua função não é a produção material, mas a produção da consciência histórica e da coerência teórico-prática da atividade de seu grupo no mundo econômico. Aqui está a importância da ampliação do conceito que Gramsci faz de intelectual: se todo homem é um intelectual, todo homem, independente de sua posição nas relações sociais, pode ter consciência histórica da sua existência nas relações de produção e elaborar uma visão de mundo coerente com seu grupo social.

Gramsci (2006b) afirma também que um grupo social que emerge das estruturas econômicas encontra, invariavelmente, categorias intelectuais preexistentes. Essas categorias de intelectuais antes orgânicas se tornaram tradicionais porque se declararam autônomas e independentes em relação à classe da qual emergiram. É o caso dos eclesiásticos, uma categoria de intelectuais organicamente ligada à taisaristocracia fundiária que monopolizava diversos serviços importantes na Europa medieval. As lutascomo a escola, a instrução, a moral e a religião e as limitações impostas a esse monopólio geraram outras categorias de intelectuais (orgânicos) favorecidas pelo poder da monarquia. Segundo Gramsci, as categorias de intelectuais tradicionais, por seu "espírito de grupo" e sua "qualificação", colocam-se como autônomas e independentes do grupo social dominante. Foi dessa forma que os eclesiásticos deixaram de ser organicamente vinculados à aristocracia, mas permaneceram exercendo atividades de intelectuais na sociedade. Para o autor, "esta autoposição não deixa de ter consequências de grande importância no campo ideológico e político" (GRAMSCI, 2006b, p.17). A existência de intelectuais tradicionais significa a elaboração de consciências históricas feitas por um grupo social anacrônico. Gramsci relaciona a posição assumida pelos intelectuais tradicionais com a filosofia idealista e qualifica como "utopia social" a crença dos intelectuais em sua independência e autonomia.

Mesmo que o conceito de intelectual tal qual concebido por Gramsci assuma que uma concepção de mundo está enraizada no mundo da produção econômica, o pertencimento a um grupo social ou outro não é algo determinado apenas pelas relações sociais e de produção material. Antes de tudo, é produto da consciência.

É preferivel "pensar" sem disto ter consciência crítica, de uma maneira desagregada e ocasional, isto é, participar de uma visão de mundo imposta mecanicamente pelo ambiente exterior, ou seja, por um dos muitos grupos sociais nos quais todos estão automaticamente desde sua entrada no mundo consciente, ou é preferivel elaborar a própria concepção de mundo de uma maneira consciente e crítica e, portanto, em ligação com este trabalho do próprio cérebro, escolher a própria esfera de atividade, "participar" ativamente na produção da história do mundo, ser o guia de si mesmo e não mais aceitar do exterior, passiva e servilmente, a marca da própria personalidade? (GRAMSCI, 2006a, p.93)

Todos pertencem sempre a um determinado grupo, no qual são compartilhadas formas de pensar e agir. A questão está em saber qual é esse grupo e qual a concepção de mundo que nele se manifesta. Se uma concepção de mundo responde a determinados problemas colocados pela realidade, o autor questiona "como é possível pensar o presente com um pensamento elaborado em face de problemas de um passado frequentemente bastante remoto e superado?" (GRAMSCI, 2006a, p.95) Quando isso ocorre, a concepção de mundo é anacrônica: os grupos sociais podem exprimir, ao mesmo tempo, a mais desenvolvida modernidade e um atraso com relação à sua posição social, sendo assim "incapazes de completa autonomia histórica". Deve-se, então, criticar a própria concepção de mundo do grupo a que se pertence. "O início da elaboração crítica é a elaboração daquilo que é realmente, isto é, um "conhece-te a ti mesmo" como produto do processo histórico até 
hoje desenvolvido, que deixou em ti uma infinidade de traços acolhidos sem análise crítica" (GRAMSCI, 2006a, p.94).

Para Gramsci, então,

seria possível dizer que todos os homens são intelectuais, mas nem todos os homens têm nas sociedades a função de intelectuais [...]. Formam-se assim, historicamente, categorias especializadas para o exercício da função intelectual; formam-se em conexão com todos os grupos sociais, mas, sobretudo, com os grupos sociais mais importantes, e sofrem elaborações mais amplas e complexas em ligação com o grupo social dominante. (GRAMSCI, 2006b, p.18)

Quanto mais complexa for a atividade econômica de uma classe, mais complexa será a elaboração intelectual e mais coerente a atividade do intelectual, sua consciência e sua visão de mundo. Isso faz com que os grupos que se desenvolvem no sentido do domínio busquem a assimilação e a conquista ideológica dos intelectuais tradicionais, visando torná-los organicamente vinculados a si.

Porém, se é verdade que os grupos produzem suas concepções de mundo imediatamente a partir de suas situações materiais e de suas relações sociais, também é fato que as relações sociais carregam contradições que se manifestam nos indivíduos como uma desagregação. Essa desagregação é mais presente nos grupos subalternos, pela ausência de autonomia e consciência histórica. A desagregação dos grupos subalternos é exatamente o que os torna subalternos em relação aos dirigentes: não puderam construir uma concepção de mundo própria de sua existência. Assim, Gramsci mostra que as lutas sociais não são apenas físicas, são também intelectuais.

Um grupo social, que tem sua própria concepção de mundo, ainda que embrionária, que se manifesta na ação e, portanto, de modo descontínuo e ocasional [...], toma emprestado a outro grupo social, por razões de submissão e subordinação intelectual, uma concepção que não é sua e a afirma verbalmente, e também acredita segui-la, já que a segue em "épocas normais", ou seja, quando a conduta não é independente e autônoma, mas sim submissa e subordinada. (GRAMSCI, 2006a, p.97)

O momento em que se dá a relação direção/subordinação é o momento da hegemonia, ou seja, o momento em que se efetiva a direção intelectual e moral de um grupo sobre outro. Gramsci analisa a hegemonia a partir das relações de força que mostram a indissociável conexão entre o mundo material das relações de produção e a consciência de classe. Essas relações de força podem ser analiticamente identificadas em diferentes momentos ou graus. O primeiro grau é ligado às estruturas objetivas. "Com base no grau de desenvolvimento das forças materiais de produção, têm-se os agrupamentos sociais, cada um dos quais representa uma função e ocupa uma posição determinada na própria produção" (GRAMSCI, 2002a, p.40). Para o autor, esse momento é estático; refere-se ao número de empresas e seus empregados, número de cidades, sua população etc. O segundo grau é o da relação de forças políticas, em que podem ser avaliadas a homogeneidade, a autoconsciência e a organização dos grupos sociais. A relação de forças políticas é analisada em três momentos: o econômicocorporativo (caracterizado pela unidade de grupos profissionais em torno de uma solidariedade exclusivamente econômica), a solidariedade de interesses entre todos os membros do grupo social no campo econômico (em que são feitas reivindicações políticas às classes dominantes) e, finalmente, o momento da hegemonia:

[...] aquele em que se adquire a consciência de que os próprios interesses corporativos, em seu desenvolvimento atual e futuro, superam o círculo corporativo, de grupo meramente econômico, $e$ podem e devem tornar-se os interesses de outros grupos subordinados. Esta é a fase mais estritamente política, que assinala a passagem nítida da estrutura para a esfera das superestruturas complexas; é a fase em que as ideologias geradas anteriormente se transformam em "partido", entram em confrontação e lutam até que uma delas, ou pelo menos uma única combinação delas, tenda a prevalecer, a se impor, a se irradiar por toda a área social, determinando, além da unicidade dos fins econômicos e políticos, também a unidade intelectual e moral, pondo todas as questões em torno das quais ferve a luta não no plano corporativo, mas num plano "universal", criando assim a hegemonia de um grupo social fundamental sobre uma série de grupos subordinados. (GRAMSCI, 2002a, p.40) 
Gramsci (2002a) explica a dialética do conceito de hegemonia na relação entre a estrutura das condições materiais de produção (manifesta nos interesses meramente econômico-corporativos) e a superestrutura das ideologias e da direção intelectual e moral (manifesta na universalidade hegemônica). É essa dialética que permite o movimento constante entre grupos dirigentes, que objetivam manter sua hegemonia, e grupos subalternos, que buscam superar sua subalternidade pela construção de uma contra-hegemonia. $\mathrm{O}$ autor afirma que, ao longo de vários períodos históricos, alternaram-se diferentes grupos sociais com diferentes concepções de mundo: os grupos subalternos do mundo clássico (escravos) e medieval (camponeses, proletários) não são os mesmos do Estado moderno. Para Gramsci, o Estado moderno abole algumas autonomias que renascem sob outras formas, como partidos, sindicato, associações de cultura etc. A hegemonia em maior ou menor grau pressupõe, portanto, concessões por parte dos grupos dirigentes, ${ }^{8}$ que levam em consideração alguns interesses dos grupos subalternos. Evidentemente, tais considerações limitam-se àquilo que não é essencial.

A hegemonia pressupõe, acima de tudo, a criação de consensos e de uma cultura. Um determinado tipo de civilização econômica, para ser desenvolvida, "requer um determinado modo de viver, determinadas regras de conduta, um certo costume" (GRAMSCI, 2001, p.52).

Gerratana (apud LIGUORI, 2007) ressalta que a hegemonia, concebida como uma estratégia para os grupos subalternos ascenderem à condição de dirigentes, não pode ser apenas considerada uma explicação da dominação burguesa nem pode ter seu valor ético-político esvaziado.

O modelo burguês, porém, não fora proposto por Gramsci como "modelo de estratégia política válido também para a classe operária"; quando "muda o referente de classe da hegemonia, também, deve mudar instrumentos e instituições; numa palavra, o aparelho da própria hegemonia". Se uma classe exploradora precisa de "formas de hegemonia que suscitem um consenso traduzível em delegação, um consenso próprio de aliados subalternos", uma classe que luta para pôr fim a toda exploração tende a "uma hegemonia sem aliados subalternos, uma hegemonia que seja educação permanente para o autogoverno". (GERRATANA apud LIGUORI, 2007, p.214)

A ressalva de Gerratana é de suma importância, pois além de reforçar o caráter transformador da obra de Gramsci, afasta qualquer interpretação puramente instrumental do conceito de hegemonia que não considere o objetivo último da libertação da humanidade. A hegemonia dos grupos subalternos busca superar os instrumentos e instituições de dominação do mundo capitalista, inclusive, o Estado moderno.

Dentre as principais análises e conceitos de Gramsci, e em estreita relação com a dinâmica da hegemonia, está o conceito de Estado. Para Gramsci, no momento em que um grupo se torna hegemônico, ele se torna Estado. Se a hegemonia educa, inculca culturas e formas de vida, com o Estado não é diferente.

Se todo Estado tende a criar e a manter um certo tipo de civilização e de cidadão (e, portanto, de convivência e de relações individuais), tende a fazer desaparecer certos costumes e a difundir outros. [...]. Na realidade, o Estado deve ser concebido como "educador", na medida em que tende precisamente a criar um novo tipo ou nível de civilização. (GRAMSCI, 2002a, p.28)

Para compreender o conceito de Estado em Gramsci, é necessário considerar a distinção metodológica entre sociedade civil e sociedade política. A sociedade civil é "o conjunto de organismos designados vulgarmente como privados", que correspondem à função de hegemonia. A sociedade política corresponde à função de domínio direto ou de comando, que se expressa no governo jurídico. Esta citação explica que na sociedade civil os intelectuais têm a função de hegemonia e na sociedade política, de governo:

Os intelectuais são os "prepostos" do grupo dominante para o exercício das funções subalternas da hegemonia social e do governo político, isto é: 1) do consenso "espontâneo" dado pelas grandes massas da população à orientação impressa pelo grupo fundamental dominante à vida social,

\footnotetext{
${ }^{8}$ Com relação aos conceitos de "dirigente" e "dominante", Gramsci utiliza as duas expressões em diversos momentos, muitas vezes, sem uma distinção conceitual precisa entre elas. Em uma passagem, entretanto, afirma que "se a classe dominante perde o consenso, ou seja, não é mais 'dirigente', mas unicamente 'dominante', detentora da pura força coercitiva, isso significa exatamente que as grandes massas se destacaram das ideologias tradicionais [...] (GRAMSCI, 2002a, p. 184). A partir dessa citação, será adotada a expressão "dirigente" para os grupos que têm hegemonia e "dominante" para grupos que dominam apenas pela coerção.
} 
consenso que nasce "historicamente" do prestígio (e, portanto, de confiança) obtido pelo grupo dominante, por causa de sua posição e de sua função no mundo da produção; 2) do aparelho de coerção estatal que assegura "legalmente" a disciplina dos grupos que não "consentem", nem ativa nem passivamente, mas que é constituído para toda a sociedade na previsão dos momentos de crise no comando e na direção, nos quais desaparece o consenso espontâneo. (GRAMSCI, 2006b, p.20)

Com relação às funções de hegemonia, os intelectuais produzem o consenso ativo das massas pela formulação de orientações dos grupos dirigentes à vida social. Quanto às funções de governo, utilizam mecanismos estatais de coerção sobre os grupos que não consentem à orientação dominante. Sociedade civil e sociedade política, conceitos oriundos de uma distinção puramente metodológica, fundem-se no Estado, algumas vezes referido pelo próprio autor como Estado integral. O Estado, em Gramsci, é precisamente a expressão, em cada momento histórico, das lutas por hegemonia que ocorrem nos organismos "privados" da sociedade civil. Assim, o autor amplia a ideia de Estado além das estruturas jurídicas e administrativas de governo, mostrando que todos os organismos da sociedade civil voltados à produção material ou intelectual (indústrias, mídia, escolas, partidos políticos) são parte de uma hegemonia e, portanto, formam parte do Estado.

Os diversos grupos da sociedade civil, de acordo com suas orientações políticas, constroem seus projetos de hegemonia com a intenção de se tornar Estado. Os grupos dirigentes, através da coerção e do consenso, mantêm sua hegemonia sobre os grupos subalternos que objetivam construir a contra-hegemonia para deixarem de ser subalternos.

O Estado é certamente concebido como organismo próprio de um grupo, destinado a criar as condições favoráveis à expansão máxima desse grupo, mas este desenvolvimento e esta expansão são concebidos e apresentados como a força motriz de uma expansão universal, de um desenvolvimento de todas as energias "nacionais"; isto é, o grupo dominante é coordenado concretamente com os interesses gerais dos grupos subordinados e a vida estatal é concebida como uma contínua formação e superação dos equilíbrios instáveis (no âmbito da lei) entre os interesses do grupo fundamental e os interesses dos grupos subordinados. (GRAMSCI, 2002a, p.41)

Inspirado em Gramsci, Campione (2003) afirma que tão ou mais importante do que conquistar o Estado é a tarefa de conceber uma "visão de mundo antagônica à predominante", reforçando as palavras de Gerratana (apud LIGUORI, 2007). Para este, uma visão de mundo antagônica à predominante é precisamente aquela que não permite a exploração e a dominação nas sociedades civil ou política, pelo sistema de produção ou pelos aparatos burocráticos de governo. É um antagonismo entre exploração, de um lado, e libertação, do outro. A obra de Gramsci mostra que, na tarefa de conceber essa visão de mundo, é imprescindível a atividade de intelectuais organicamente vinculados às transformações de seu tempo. Para tanto, ressalta a necessidade de identificar, nos momentos da história em que as classes subalternas se tornaram dirigentes, "as fases através das quais elas adquiriram a autonomia em relação aos inimigos a abater e a adesão dos grupos que a ajudaram ativa ou passivamente" (GRAMSCI, 2002b, p.141). Ele se refere, ainda, à questão do consenso: a adesão de outros grupos a uma ideologia, uma forma de pensar, de se comportar; enfim, é a adesão a uma cultura e a uma filosofia. Por esse motivo, sua obra está sempre no terreno da filosofia da práxis.

A frase do escritor francês Romain Rolland "pessimismo da inteligência, otimismo da vontade", tantas vezes citada por Gramsci, sintetiza o pensamento do autor italiano e renova as esperanças daqueles que não se conformam com a realidade que se apresenta. "É necessário criar homens sóbrios, pacientes, que não se desesperem diante dos piores horrores e não se exaltem em face de qualquer tolice. Pessimismo da inteligência, otimismo da vontade" (GRAMSCI, 2006b, p.267).

\section{Paulo Freire: denúncla e anúncio}

Para Dussel (2002, p.427), Freire possui uma originalidade própria; não é simplesmente um pedagogo, no sentido específico do termo. "É um educador da "consciência ético-crítica"”. Inspirando-se em Hegel, MerleauPonty, Sartre, Mounier, Jaspers, Marx e Lucáks, entre outros, Freire desenvolveu um discurso próprio, a partir 
da realidade do Nordeste brasileiro e da América Latina. Dussel (2002, p.443) ainda ressalta, com especial atenção, que quando Freire aborda o "medo da liberdade" presente no oprimido, introjetado pelo castigo e pela dominação, "pulsionalmente, inspira-se, com certeza, em Erich Fromm, e nisto, Freire é sucessor da primeira escola de Frankfurt em sua materialidade negativa".

Freire (2005a) afirma que para sua libertação, antes de tudo, o oprimido precisa descobrir-se como tal para, então, elaborar sua "consciência crítica", passo a passo com sua organização. Trata-se de uma luta, ao mesmo tempo, interna e coletiva: interna porque dentro do oprimido também vive o opressor; coletiva porque a libertação não é uma luta individual, é social e política. É uma libertação que não é unilateral, pois a libertação do oprimido deve dar-se junto com a libertação do opressor; caso contrário, seria mera repetição dos mesmos métodos e procedimentos de dominação. O objetivo que é libertador nega qualquer coisificação. Nesse sentido, é trágico o dilema dos oprimidos e o que têm que enfrentar:

a liberdade só é viável na e pela superação da contradição opressores-oprimidos, que é a libertação de todos. A superação da contradição é o parto que traz ao mundo esse homem novo não mais opressor, não mais oprimido, mas homem libertando-se (FREIRE, 2005a, p.38).

É em Pedagogia do oprimido que Paulo Freire desenvolve e utiliza pela primeira vez o sintagma inédito-viável, "epistemologicamente empregado [...] para expressar, com enorme carga afetiva, cognitiva, política, epistemológica, ética e ontológica, os projetos e os atos da possibilidade humana" (ARAÚJO FREIRE, 2008, p.231). Segundo Freire (2005), o inédito-viável se nutre da inconclusão humana, mostra as possibilidades históricas, informa que não há reino do definitivo, do pronto e do acabado. O inédito-viável é a utopia alcançada que faz brotar outros inéditos-viáveis. Freire (2005a, p.104) explica o inédito-viável a partir da concepção de que os seres humanos não somente vivem, mas existem; existência que é histórica. $\mathrm{O}$ autor observa ainda que estes são consciência de si mesmos e, assim, consciência do mundo, porque são "corpo consciente" e vivem uma relação dialética entre os condicionamentos e sua liberdade. Desse modo, em suas relações com o mundo e com os outros, os sujeitos podem ultrapassar as situações-limite ${ }^{9}$, que não devem ser tomadas como se fossem barreiras insuperáveis, mas apenas como obstáculos à sua libertação, ou, ao não enfrentá-las, tomá-las como barreiras intransponíveis.

No momento mesmo em que os homens as apreendem [as barreiras] como freios, em que elas se configuram como obstáculos à sua libertação, se transformam em "percebidos-destacados" em sua "visão de fundo". Revelam-se, assim, como realmente são: dimensões concretas e históricas de uma dada realidade. Dimensões desafiadoras aos homens, que incidem sobre elas através de "atoslimites". (FREIRE, 2005a, p.104)

Para Freire (2005a), a superação das situações-limite não ocorre fora das relações ser humano-mundo. Na verdade, somente acontece através da ação dos sujeitos sobre a realidade concreta em que se dão tais situações.

Portanto, são as barreiras, as situações-limite depois de "percebidos-destacados", que permitem o sonho da realização da utopia da humanização, a concretização do SER MAIS e da autêntica Democracia. (ARAÚJO FREIRE, 2008, p.233)

Segundo Dussel (2002, p.437), "trata-se de um ponto de partida material, analítico, econômico e político". Assim, "se Horkheimer nos diz que negatividade e materialidade são as condições da teoria crítica, aqui, não só temos uma teoria, mas uma prática crítica de muito maior negatividade e materialidade". Nessa realidade, já não é a "teoria crítica de cientistas que procuram um 'sujeito' histórico: são os 'sujeitos históricos' que buscam antes quem possa educá-los" em comunidade, pois aí se educam também os cientistas (DUSSEL, 2002, p.437), posto que não se separa o ato de ensinar do ato de aprender (FREIRE, 1984). Ao contrário, Paulo Freire afirma

\footnotetext{
${ }^{9}$ As situações-limite são "a margem real onde começam todas as possibilidades; não são a fronteira entre o ser e o nada, mas a fronteira entre o ser e o ser mais" (PINTO, 1960, p.284). São barreiras concretas que precisam ser vencidas. Diante delas, os seres humanos têm várias atitudes: ou as percebem como um obstáculo que não podem transpor ou como algo que não querem transpor ou, ainda, como algo que sabem que existe e que precisa ser rompido. Nessa última hipótese, a situação-limite foi percebida criticamente e, por isso mesmo, é possível agir para superá-la (ARAÚJO FREIRE, 2008, p.232).
} 
a educação como um ato político, negando qualquer possibilidade de que esta venha a ser neutra. Desse modo, analisa o papel histórico-político do educador como uma possibilidade histórica e essencial da práxis revolucionária.

Ao mesmo tempo em que salienta o papel de respeito do educador ou da educadora pela autonomia do educando ou educanda, também ressalta que a educação não é voluntarista; ou seja, o educador também tem um papel a cumprir no desenvolvimento da reflexão crítica sobre a prática do educando ou educanda. Essas reflexões são aprofundadas em Pedagogia da autonomia, onde Freire (2006, p.47) afirma que "ensinar não é transferir conhecimento, mas criar possibilidades para sua própria produção ou a sua construção". Isto é, "ensinar exige a convicção de que a mudança é possível [...] é o saber da História como possibilidade e não como determinação". Exige a compreensão de que "o mundo não é. O mundo está sendo". Exige que o educador ou a educadora se pergunte constantemente: "em favor de que estudo? Em favor de quem? Contra que estudo? Contra quem estudo?" (FREIRE, 2006, p.76-77).

"O inédito-viável é, pois, uma categoria que encerra nela mesma toda uma crença no sonho e na possibilidade de utopia, na transformação das pessoas e do mundo. É, portanto, tarefa de todos e todas" (ARAÚJO FREIRE, 2008, p.234). Porém, como salienta Freire (2005a), o inédito-viável depende, a priori, de certa conscientização e posicionamento diante da realidade, da percepção da possibilidade de transformar a realidade. De acordo com Dussel (2002), aqui está, claramente, o papel do educador em Paulo Freire: possibilitar o descobrimento do sujeito de sua própria condição real e histórica. Freire (2005b) lembra que aí está limitado também o papel do educador, pois a consciência não chega ao sujeito vinda "de fora", surge "de dentro". A conscientização não se dá apenas no nível das ideias, mas na ação (FREIRE, 1980). O ser humano se modifica ao mesmo tempo em que modifica o mundo. Portanto, a conscientização como atitude crítica dos homens na história não finda jamais; é um processo permanente de busca e aprendizado através da ação e da reflexão, na tentativa de superar obstáculos; é a permanente busca da utopia. Esta, para Freire (1980, p.27),

não é o irrealizável; a utopia não é o idealismo, é a dialetização dos atos de denunciar e anunciar, o ato de denunciar a estrutura desumanizante e anunciar a estrutura humanizante. Por essa razão, a utopia é também um compromisso histórico.

Ao refletir sobre o processo de conscientização, Freire $(1980,2005 b)$ assinala que não ocorre uma simples passagem de uma consciência mágica ou ingênua para uma consciência crítica. Caracteriza, então, três graus de consciência da realidade, em parte, condicionados pela estrutura histórico-cultural. O primeiro grau é a "consciência intransitiva", marcada pela falta de discernimento acerca da realidade, implicando uma incapacidade de entender as diversas problemáticas que cercam o sujeito. Nesse estágio, ele não consegue exprimir-se, pois se encontra ainda em si e não é capaz de chegar à autoconscientização do para si. Porém, à medida que o sujeito dialoga sobre questões transcendentes à esfera meramente vital, sua consciência se alonga em um processo transitivo que Freire (1980) chama de "consciência ingênua". Nesse segundo grau de consciência, o sujeito possui uma compreensão mágica da realidade, perceptível na fragilidade de suas argumentações. A escuta do outro ainda não é sensível, as concepções são consolidadas individualmente. A partir da "consciência ingênua" pode emergir o terceiro grau de consciência da realidade, a "consciência crítica", marcada pela segurança de argumentos, pela recusa a qualquer tipo de autoritarismo e dominação, e pela presença do diálogo e do compromisso com a libertação e a emancipação do ser humano. Compreende-se, então, que a "consciência crítica" se dá pela "ação dialógica".

O diálogo não impõe, não maneja, não domestica, não sloganiza. Não significa isto que a teoria da ação dialógica conduza ao nada. Como também não significa deixar de ter o dialógico uma consciência clara do que quer, dos objetivos com os quais se comprometeu. [...] Aqui, propriamente, ninguém desvela o mundo ao outro e, ainda quando um sujeito inicia o esforço de desvelamento aos outros, é preciso que estes se tornem sujeitos do ato de desvelar. O desvelamento do mundo e de si mesmas, na práxis autêntica, possibilita às massas populares a sua adesão. (FREIRE, 2005a, p.198199) 
A questão central da ação dialógica é que ela não se dá fora da práxis. Isto é, o diálogo, o pensar, "não se dá fora dos homens, nem num homem só, nem no vazio, mas nos homens e entre os homens, e sempre referido à realidade" (FREIRE, 2005a, p.117).

Para emergir como sujeito histórico, o sujeito da história precisa pensar o seu próprio pensar. "Se o pensar é mágico ou ingênuo, será pensando o seu pensar, na ação, que ele mesmo se superará. E a superação não se faz no ato de consumir ideias, mas no de produzi-las e de transformá-las na ação e na comunicação" (FREIRE, 2005a, p.117).

Desse modo, sendo os homens seres em "situação", sujeitos que se encontram enraizados em condições tempo-espaciais que os marcam e a que eles igualmente marcam, sua tendência é refletir sobre sua própria situacionalidade, na medida em que, desafiados por ela, agem sobre ela. Essa reflexão implica, por isso mesmo, algo mais que estar em situacionalidade, que é a sua posição fundamental. Os homens são porque estão em situação. E serão tanto mais quanto não só pensem criticamente sobre sua forma de estar, mas criticamente atuem sobre a situação em que estão. (FREIRE, 2005a, p.118)

Essa reflexão sobre a situacionalidade da qual trata Freire (2005a) é um pensar a própria condição de existir, um pensar crítico através do qual os homens se descobrem em "situação". "Da imersão em que se achavam, emergem, capacitando-se para se inserirem na realidade que se vai desvelando. Desta maneira, a inserção é um estado maior que a emersão e resulta da conscientização da situação. É a própria consciência histórica" (FREIRE, 2005a, p. 118). É essa noção de historicidade que permite os inéditos-viáveis, partindo, inclusive, da própria denúncia de uma estrutura desumanizante, a qual não é possível desvendar sem conhecer por dentro. Afinal, não é possível denunciar se não conheço, assim como não é possível denunciar sem anunciar.

Freire desvelou inéditos-viáveis fundamentais de nossa sociedade, denunciando-os, contraditoriamente anunciando o anúncio esperançosamente viável. Denunciar e denúncia com toda a presença do repudiante, do desumanizante e do antiético que o inédito-viável mesmo anuncia sobre o que é ineditamente-viável, o sonho utópico. Anunciar e anúncio com toda a carga de generosidade, de humanismo e de esperança de futuro que lhes são próprios. (ARAÚJO FREIRE, 2008, p.233)

Para Freire (1980), a própria existência consciente está presente no sintagma denúncia-anúncio. Assim como o inédito-viável, essa é outra unidade inquebrantável criada por ele. É percebendo e vivendo a história como possibilidade que se experimenta a capacidade de comparar, de ajuizar, de escolher, de decidir, de romper, de intervir no mundo e de avaliar a intervenção.

Na História como possibilidade não há lugar para o futuro inexorável. Pelo contrário, ele é sempre problemático [...] Nenhuma realidade é assim porque assim tem de ser. Está sendo assim porque interesses fortes de quem tem poder a fazem assim. (FREIRE, 2000, p.126)

Entretanto, reconhecer não basta, é apenas uma parte. Posicionar-se diante desse reconhecimento, e agir por causa dele, é o que faz do ser humano um sujeito histórico. "Um ser da intervenção no mundo à razão de que faz a História. Nela, por isso mesmo, deve deixar suas marcas de sujeito e não pegadas de puro objeto" (FREIRE, 2000, p.119). Posicionar-se, portanto, implica pensar na concretude da realidade, implica denunciar como estamos vivendo e anunciar como podemos viver. Um sem o outro é mera retórica, é discurso vazio. No sintagma denúncia-anúncio, segundo Dussel (2002), Freire indica que há um momento negativo, da crítica, e outro positivo, da utopia, do inédito-viável. A denúncia é o fruto da comunidade dialógica dos oprimidos com consciência crítica em dialética colaboração com sujeitos em posição interdisciplinar. Já a utopia é o uso da imaginação criadora de alternativas, que se baseia no que deveria ser e não no que é (DUSSEL, 2002). Como afirma Linhares (2008, p.45), é um sintagma de tal importância que "qualquer cartografia da obra de Paulo Freire, nela considerando a própria estética de sua existência, sem as lógicas do anunciar-denunciando ou do denunciar-anunciando que a impregnam, torna-se um mapa simplificado". 
O sintagma denunciar-anunciar está imbuído da afirmação freireana de que a realidade é processo e não um fato dado. Entretanto, também ensina que não há possibilidade de pensar o amanhã "sem que nos achemos em processo permanente de 'emersão' do hoje, 'molhados' do tempo que vivemos, tocados por seus desafios, instigados por seus problemas" (FREIRE, 2000, p.117). Pensar o amanhã, para Freire (2000), é fazer profecia.

Só que o profeta é o que fundado no que vive, no que vê, no que escuta, no que percebe, no que intelige, à raiz do exercício de sua curiosidade epistemológica, atento aos sinais que procura compreender, apoiado na leitura do mundo e das palavras, antigas e novas, à base de quanto e de como se expõe, tornando-se assim cada vez mais uma presença no mundo à altura de seu tempo, fala, quase adivinhando, na verdade, intuindo, do que pode ocorrer nesta ou naquela dimensão da experiência histórico-social. (FREIRE, 2000, p.118)

Isso implica que aquele que denuncia-anuncia só o faz a partir de determinado posicionamento consciente no mundo. Obviamente, na denúncia-anúncio, considera-se o posicionamento ideológico daquele que o emprega, uma vez que aqueles que fazem ou utilizam as ciências político-sociais, bem como a própria ciência, também não são neutros. Não significa tampouco que a perspectiva profética, utópica e esperançosa fale de um mundo de sonhos impossíveis, pois esta requer, também, o conhecimento científico do mundo concreto. "Ser profético, utópico e esperançoso é denunciar e anunciar através da práxis real. Daí o conhecimento científico da realidade como condição necessária à eficiência profética" (FREIRE, 1984, p.125).

"Sublinhe-se ainda que a inteligência da História como possibilidade implica reconhecer ou constatar a importância da consciência no processo de conhecer, de intervir no mundo" (FREIRE, 2000, p.126). Nesse sentido, na medida em que a verdadeira utopia implica na dialetização da denúncia e do anúncio, não é possível denunciar a realidade sem conhecê-la, tampouco, anunciar a nova realidade sem ter um pré-projeto que, emergindo na denúncia, somente se viabiliza na práxis (FREIRE, 1984). De acordo com o autor, também não é verdadeira uma denúncia que se baseia no conhecimento distante da realidade tratada, tanto quanto a denúncia e o anúncio solitário; ou seja, aqueles que não se dão em comunhão com as massas populares. Esse tipo de denúncia empresta às massas populares caráter de vítimas que precisam ser salvas e anunciam um futuro que se instalaria automaticamente, independentemente da ação consciente dos seres humanos. Esse tipo de denúncia e anúncio atenta contra qualquer projeto emancipatório do ser humano; é demonstração de ingenuidade política e de desconhecimento da necessidade temporal da história. Desse modo, segundo Freire (2000), o primeiro ato político é aprender que o processo de denunciar-anunciar está diretamente relacionado ao tempo histórico e que, sendo possibilidade, demanda um compromisso histórico com o tempo necessário para a transformação do mundo, ou seja, de homens e mulheres.

Não há anúncio sem denúncia, assim como denúncia gera anúncio. Sem este, a esperança é impossível. [...] Não há como falar em esperança se os braços se cruzam e passivamente se espera. Na verdade, quem espera na pura esperança vive um tempo de espera vã. A espera só tem sentido quando, cheios de esperança, lutamos para concretizar o futuro anunciado, que vai nascendo na denúncia militante. (FREIRE, 1984, p.59)

Certamente, não é no silêncio que se faz a denúncia-anúncio, mas na ação dialógica, na palavra, pois é com estas que os sujeitos transformam o mundo. Porém, a palavra é mais que um meio para que o diálogo se faça. Nela se encontram duas dimensões: "ação e reflexão, de tal forma solidárias, em uma interação tão radical que, sacrificada, ainda que em parte, uma delas se ressente imediatamente da outra. Não há palavra verdadeira que não seja práxis" (FREIRE, 2005a, p. 89). Assim, se a palavra que denuncia-anuncia resulta da dicotomia, é mero engodo. Se sacrificada a dimensão da ação, então, é verbalismo alienado e alienante, é palavra oca da qual não se pode esperar a denúncia do mundo, pois não há denúncia sem compromisso de transformação, nem este sem ação. Se, pelo contrário, enfatiza-se a ação em detrimento da reflexão, é puro ativismo, ação pela ação que, ao negar a reflexão, nega também o diálogo (FREIRE, 2005a).

"Qualquer dessas dicotomias, ao gerar-se em formas inautênticas de existir, gera formas inautênticas de pensar, que reforçam a matriz em que se constituem", impossibilitando, portanto, o pronunciamento do mundo, ou seja, a denúncia-anúncio que viabiliza a existência humana. "Existir, humanamente, é pronunciar o mundo, é 
modificá-lo. E o mundo pronunciado, por sua vez, se volta problematizado aos sujeitos pronunciantes, a exigir deles novo pronunciar" (FREIRE, 2005a, p.90). Nesse sentido, o sintagma denúncia-anúncio não é vazio, mas compromisso histórico. Mover-se entre a denúncia e o anúncio é uma ação constante, pois não se esgota quando a realidade denunciada cede lugar à nova, mais ou menos anunciada naquela denúncia (FREIRE, 1984). Isso é fazer história: ser histórico é transformar a própria realidade.

\section{Bloch, Gramsci e Freire: aproximações}

A utopia concreta presente nos textos de Bloch, Gramsci e Freire, de exegese filosófico-político-educativa, fundada na práxis militante, insurge-se contra o pensamento que ameaça a imaginação e impõe obstáculos à possibilidade da libertação humana. Essa breve aproximação só é possível porque elas guardam importantes afinidades epistemológicas e históricas. Também são encontradas afinidades biográficas entre esses autores, o que, provavelmente, colabora para a produção do significado dos seus escritos em nossas leituras e interpretações.

Bloch, judeu, nascido na Alemanha, viveu o período da I Guerra e a ascensão do nazismo, que o obrigou a se refugiar na Suíça. Esse filósofo marxista teve, ainda, que emigrar outras vezes por motivos políticos: de 1917 a 1919, em protesto contra a política bélica alemã, e em 1961, quando decidiu morar na Alemanha Ocidental, em oposição à construção do muro de Berlim. Em 1957 havia sido retirado de sua cátedra, em Leipzig, em que trabalhava os escritos de Marx, bem como lhe foi proibida qualquer atividade docente (ERNST BLOCH, 2004). Gramsci, por sua vez, era oriundo da Sardenha, uma região pobre do sul da Itália, onde o analfabetismo atingia altíssimos índices. Com a subida de Mussolini ao poder, Gramsci, então membro do Parlamento pelo Partido Socialista Italiano, foi preso. Porém, isso não impediu sua práxis, pois no cárcere, além de traduzir os escritos de Marx e de outros autores, analisava a situação político-social da Itália, sempre com a preocupação de contribuir para as lutas que ocorriam naquele momento. Freire, oriundo de uma das áreas mais pobres e com maiores índices de analfabetismo do Brasil, o Nordeste, também possui um trabalho que responde às questões históricas e às exigências políticas de sua época. Devido ao seu trabalho, após o golpe militar de 1964, Freire foi preso e depois exilado por quase 20 anos, sem poder retornar ao seu país de origem. Em suma, os autores trabalhavam em contextos politicamente conflagrados e, como intelectuais orgânicos, produziram conhecimento para o enfrentamento dos problemas de seu tempo, em solidariedade com as massas dominadas e exploradas.

Bloch, Gramsci e Freire consideram a realidade como um processo histórico. Suas obras estão marcadas pela materialidade e pela dialética nos processos subjetivos e sociais, bem como, pela necessidade de conscientização do ser humano para que este, de objeto, torne-se sujeito da história. Essas características imprimem nas suas obras um caráter ímpar: a convicção da vida como fundamento e a esperança concreta como elemento que a torna viável. É essa relação que também os coloca no terreno do marxismo, pois é a partir da análise da realidade e de suas contradições históricas que suas formulações avançam no sentido da libertação da humanidade.

Bloch parte do conteúdo radical e material da vida para afirmar que a esperança, ainda que seja um princípio subjetivo, é fundada na práxis histórica e material. A esperança pode ser uma esperança concreta, pois tem raízes nas demandas mais urgentes do ser humano: a fome e a autopreservação. Contemporâneo de Bloch, Gramsci fez da práxis a sua arma contra a miséria material, moral e intelectual. É por isso que, mesmo encarcerado pelo regime fascista, continuou sua luta para transformar o mundo, recorrendo ao desenvolvimento de uma filosofia que é também uma política, a filosofia da práxis, a qual visa conduzir grupos subalternos a uma concepção de vida superior, do ponto de vista material e intelectual. Para Gramsci, os mais elevados valores da humanidade estão na defesa da própria existência física. Por sua vez, em sua práxis, Freire propôs a educação da "consciência ético-crítica", cujo fundamento está ontologicamente enraizado na vida, no ser humano como um ser da práxis, tendo como objetivo a libertação humana a partir da conscientização. Para Freire, a esperança é uma condição existencial, uma necessidade ontológica que, como tal, precisa da prática 
para tornar-se concretude histórica. Nesse sentido, é inegável a influência direta ou indireta de Gramsci e de Bloch nas formulações de Freire.

Ao tratar do tema do "intelectual", Gramsci afirma que todos os homens são intelectuais, ou seja, que todos possuem capacidade de realizar uma elaboração intelectual, a qual se manifesta tanto nas atividades profissionais quanto nas visões de mundo, nos gostos particulares etc. Assim, Gramsci rejeita a separação entre os intelectuais acima e os simples, abaixo, afirmando a necessidade de um progresso intelectual e moral de massa. Se a defesa da própria existência é a afirmação do mais elevado valor da humanidade, a superação da precariedade material não pode ser um passo anterior ou posterior à superação da precariedade intelectual e moral, uma vez que são processos simultâneos. Na mesma direção, Freire (in GADOTTI, FREIRE, GUIMARÃES, 1995, p.54) afirma que: "para mim, o caminho gramsciano é fascinante. É nessa perspectiva que me coloco. No fundo, tudo isso tem a ver com o papel do chamado intelectual orgânico, que Gramsci estuda tão bem e tão amplamente".

Ainda refletindo acerca do tema, Freire assinala, em entrevista, que "pensar sobre o intelectual e o seu papel, sua prática inserida numa prática maior, a social, nos leva necessariamente a refletir sobre o seu sonho, que é político" (FREIRE; FAUNDEZ, 1998, p.35).

Quanto mais o intelectual se exponha a este aprendizado, através do qual vai virando um novo intelectual, tanto mais percebe que o ponto de partida para a transformação da sociedade não está própria e exclusivamente no seu sonho, não está na sua compreensão da história, mas na compreensão das classes populares. É a partir daí, molhando-se nas águas culturais e históricas, nas aspirações, nas dúvidas, nos anseios, nos medos das classes populares que, organicamente, vai inventando com elas caminhos verdadeiros de ação [...] Sem renunciar a sua experiência de intelectual, o conhecimento sistemático dela advindo, pelo contrário, junta àquela experiência o saber das massas. Aprendendo a mobilizá-las mobilizando-as e mobilizando-se na mobilização que faz, aprendendo a organizar-se organizando-se e organizando, aprende a reconhecer a importância de seu papel, sem superestimá-lo nem tampouco subestimá-lo. (FREIRE; FAUNDEZ, 1998, p.36)

O autor também questiona o que fazer para a realização do sonho, considerando que, a priori, este dever ser "a encarnação de virtudes ou qualidades que o intelectual tem de viver, no sentido de aproximar ao máximo o seu discurso de sua prática". Nessa perspectiva, Freire (Ibidem, p.35) afirma que "uma condição fundamental, na discussão do papel do intelectual com relação a seu sonho, é que o seu sonho seja um sonho possível de ser realizado e que sua realização a perseguir o seja nas concretas condições em que se acha". O sonho a que Freire se refere foi teorizado por Bloch no conceito de "sonho diurno". ${ }^{10}$ Os "sonhos diurnos" se originam na fome, podendo proporcionar ideias e elaboração mental, esperança fundada nas condições materiais. Dessa esperança, surge a confiança na realização, creditando àquela uma função utópica, pois, originada no impulso mais básico do ser, pode elaborar um "ainda-não existente" na esperança concreta. Isto é, uma recusa em separar a condição material da capacidade criadora, imaginativa e transformadora presente nas obras de Bloch, Gramsci e Freire.

Freire pode ser considerado um herdeiro de Bloch, quando assume a possibilidade da transformação do sonho em realização, e de Gramsci, quando trata da inseparabilidade entre atividade física e intelectual. O método Paulo Freire é a expressão concreta dessa perspectiva, pois o autor mostra que o ato de ensinar não é mera transferência de conhecimento, é criação de possibilidades de produção do conhecimento pelos próprios sujeitos, em cada época histórica, produzindo sentido à sua práxis. Entretanto, esse sentido só é produzido a partir das realidades materiais de cada classe social e com os sujeitos daquela classe, através do diálogo que pode conduzir à consciência crítica e, portanto, à recusa a qualquer tipo de autoritarismo e dominação. Assim,

\footnotetext{
${ }^{10}$ Paulo Freire não faz referência a Ernest Bloch em seus textos. Todavia, Bloch foi contemporâneo de Erich Fromm, com quem trabalhou na escola de Frankfurt. Fromm, por sua vez, era amigo de Freire, que com ele discutia seus escritos. Fromm é mencionado com certa frequência nos textos de Freire. Este, inclusive, quando se refere a Fromm, sempre o faz com muito zelo. Em certo momento, quando se refere a uma de suas conversas com Fromm a respeito de sua "pedagogia do oprimido", Freire (2001) afirma que sempre volta à sua memória o momento em que ouviu de "Erich Fromm, em sua casa, em Cuernavaca, olhos miúdos, azuis, brilhantes: "Uma prática educativa assim é uma espécie de psicanálise histórico-sociocultural e política”".
} 
ninguém educa ninguém e os homens e mulheres se educam em sociedade; ninguém liberta ninguém e os seres humanos se libertam em sociedade, a partir da consciência crítica.

Enquanto Freire explica o nascimento da consciência crítica através do diálogo, ou seja, em comunhão com outros, Gramsci traz essa consciência crítica para o centro da filosofia da práxis. Para Gramsci, a crítica do processo histórico, que deixou como legado uma infinidade de traços acolhidos do passado, leva à consciência crítica do grupo a que se pertence, bem como de sua concepção de mundo. O "pensar" crítico é essencial para que não sejam aceitas visões de mundo impostas, superando-se, assim, o anacronismo dos pensamentos elaborados a partir de problemas do passado. É esse "pensar" que gera uma filosofia comprometida com a superação da condição de subalternidade. Quanto a Bloch, este aprofunda a reflexão sobre a consciência, recorrendo à psicanálise para explicar os processos de elaboração criativa que permitem que a esperança seja concreta. É na pré-consciência que alvorece algo que não foi reprimido e nem é subordinado pela consciência; é um "ainda-não-consciente", o local na psique onde nasce o novo. O "ainda-não-consciente" encontra um bloqueio histórico e social que recusa o novo. Para superar esse bloqueio, é necessário um conhecimento cuja referência não seja o passado, mas aquilo que está por vir.

Ainda que através de análises distintas, os três autores convergem na afirmação da necessidade da conscientização para a libertação. Freire enfatiza que a consciência crítica e a libertação só ocorrem em grupo e pelo diálogo. Gramsci afirma que os grupos subalternos somente podem se libertar da subordinação intelectual a partir da autocrítica dos modos de pensar hegemônicos. Bloch propõe a produção de um conhecimento que possibilita essa autocrítica e anuncia o nascimento daquilo que "ainda-não-é", como o fez a filosofia iniciada por Karl Marx.

Algumas suposições podem ser feitas sobre a aproximação entre os autores. De acordo com Ayuste (1997), Gramsci, além de influenciar a pedagogia crítica desenvolvida por Freire, foi um dos grandes influenciadores da teoria crítica da escola de Frankfurt, por meio de seus representantes mais significativos, como Horkheimer, Marcuse, Adorno e, principalmente, através da terceira geração dessa escola, da qual participaram Erich Fromm e Ernst Bloch. A autora ainda assinala que o marxismo ocidental tem Gramsci como um de seus principais fundadores, junto com Lukács, Bloch e Korsch, e que eles estavam em profundo desacordo com a disseminação de um materialismo histórico determinista que ia de encontro ao materialismo histórico encontrado em Marx. A influência gramsciana na escola de Frankfurt se dá, também, em oposição ao projeto iluminista, caracterizado pela exaltação do novo e do culto à razão e à verdade objetiva. Sob a influência de Gramsci é que se origina a proposta da libertação dos sujeitos e da luta contra as desigualdades sociais a partir da crítica ao desenvolvimento como mera modernização (PALOS, 2005, p.13).

É de se observar que tanto em Bloch quanto em Gramsci existe uma recusa da leitura positivo-mecanicista do materialismo histórico. Esses dois autores sublinham o momento da subjetividade, da consciência e da práxis (LOSURDO, 1998). Em Gramsci, a práxis é uma filosofia popular, uma filosofia que nasce das práticas dos homens em suas atividades produtivas e criativas, a qual permite ao subalterno a consciência crítica de sua situação de subalternidade, ao mesmo tempo em que fornece os meios para a superação dessa condição pela construção de uma visão de mundo própria de sua existência. Para Bloch, é essa práxis que coloca a esperança no concreto, que faz com que a esperança não seja apenas esperar, mas um esperar que não permite conformarse com o precário que aí está, que não permite a resignação. A práxis em Bloch se expressa no correlato da possibilidade, o vermelho frio e o vermelho quente. O primeiro, analítico, é o das determinações críticas e impreteríveis que iluminam a teoria-práxis revolucionária a partir de uma análise fria e de uma estratégia precisa; o segundo, prospectivo, é o entusiasmo da inexaurida plenitude da expectativa, é o otimismo militante. $\mathrm{O}$ vermelho frio de Bloch é o pessimismo da inteligência de Gramsci: a elaboração crítica daquilo que realmente é e das formas de pensar como produto do processo histórico. O vermelho quente é o otimismo da vontade, a elaboração crítica daquilo que deve ser a partir de uma nova filosofia de vida e de uma nova cultura. Em Freire, a dialética da filosofia da práxis aparece no sintagma "denunciar-anunciar", ou seja, denunciar como estamos vivendo e anunciar como podemos viver. Para esse autor, a libertação do oprimido somente ocorre quando da descoberta da própria situação de oprimido. O momento que para Bloch é frio e para Gramsci é pessimista, para Freire é negativo, é o momento da crítica. O momento positivo é o momento da utopia, é o 
momento quente e otimista. O vermelho quente, a vontade otimista e o anúncio só se concretizam na práxis, na inseparabilidade entre atividade física e mental, entre as relações de classe vividas e os processos históricos que as produzem; enfim, entre a condição real e aquela que se pretende que venham a ser.

A "utopia em ação", uma utopia que é sonho, transforma-se em projeto e este, quando se viabiliza, torna-se esperança concreta. O projeto é o "idealizado" para Freire, é aquilo que "ainda-não-é" em nenhum lugar para Bloch, mas que ganha existência quando é posto em ação, a partir da construção daquilo que para Gramsci é a construção da contra-hegemonia. É a realidade "se dando", nunca encerrada em si mesma: um processo se construindo infinita e historicamente.

É incontestável a aproximação entre os escritos de Bloch e Freire. Para Freire, a esperança é condição de possibilidade necessária, mas não suficiente, do projeto de uma vida plena para a humanidade. Segundo o autor, a esperança em si mesma não transforma nada, não muda a realidade. É o sonho desperto, o sonho consciente, que viabiliza a articulação entre os sujeitos e converte a esperança em condição de possibilidade capaz de orientar a ação política transformadora da realidade. Desse modo, como assinala Martínez (2004, p.202), "sonhar, para Freire, é um ato político necessário, mas também é uma conotação da forma históricosocial de estar sendo homens e mulheres, em permanente processo de discernimento".

Na utopia freireana, o sonho e a esperança guardam uma relação íntima, não só entre si, mas com a história, trata-se de uma concepção dinâmica da história entendida como possibilidade, como projeção. [...] A concepção dinâmica da esperança é para Freire e Bloch um elemento vital da utopia. A história como possibilidade é ininteligivel sem sonho e sem desejo de realização. Não se pode fazer história sem projeto, sem visão utópica que permita superar o presente que foi construído ontem. É impossivel existir plenamente sem sonhar; a utopia não é possivel se lhe falta o gosto pela liberdade e pela esperança. (MARTÍNEZ, 2004, p.202)

Portanto, para Bloch e Freire, a visão utópica consiste numa tarefa permanente de construção na vida cotidiana, o que implica ação e reflexão.

Utopia é possibilidade de transcender o amanhã sem cair em idealismos ingênuos. [...] Em outros termos, a dialética entre pensar e atuar, o compromisso com a ação cultural, a conscientização no sentido de politização nos remete tanto à assunção de uma forma vigorosa de crítica ideológica, como o tomar parte de uma prática. (USTARITZ, 1996, p.24-25)

Dussel (1999, p.135) ainda afirma que os sujeitos ao se organizarem em uma "comunidade de vida e de comunicação, devem criticar o sistema que os nega (negatividade) e projetar uma alternativa futura que os transforme ou substitua (positividade). Aqui, Freire (com sua pedagogia da libertação) ou Bloch (com seu princípio da esperança) são pensadores imprescindíveis". Isso implica conscientizar e politizar para a transformação, o que acontece no próprio processo de construir a contra-hegemonia, há muito vislumbrada por Gramsci como necessária para a libertação. Como se observa, a realidade como processo histórico e a libertação do ser humano das condições de opressão (materiais e intelectuais) estão presentes nas obras dos três autores. Se para Freire a libertação do oprimido é também a libertação do opressor, caso contrário, seria mera repetição dos métodos de dominação, para Gramsci, os subalternos devem tornar-se hegemônicos, não pela criação de novas subalternidades, mas pela concepção de uma nova direção intelectual e moral que seja comprometida com o mais alto valor do ser humano: a própria existência. Do mesmo modo, para Bloch, a libertação é imanente ao ser humano, à existência humana; não a uma parte dessa humanidade. Por conseguinte, a libertação também é concebida pelos três autores como um processo, da mesma forma que a hegemonia, que nunca é total, fixa ou definitiva, ou a realidade que está sendo o tempo todo. Nesse sentido, é mais que necessário educar para a esperança, posto que prescindir da esperança é tomar a realidade como dada e o futuro, como inexorável. 


\section{Considerações finais}

A inspiração que encontramos nesses autores e a afinidade que identificamos em suas construções têm sido marcantes em nosso trabalho. Ainda que não façamos reiteradas e expressas referências, com eles compartilhamos a linguagem, as categorias e a postura militante. Esses autores autorizam posições que vinculam a crítica ao sistema com a utopia presente e concreta, em nossa aprendizagem na interação com os movimentos e lutadores sociais.

Assumir essa postura inclui a difícil prática de revisar nossas suposições de "saber fazer", de "saber a resposta", que não correspondem nem à experiência que se desenvolve em nosso tempo, nem às necessidades dos atoressujeitos envolvidos nas lutas sociais. Supõe, em vez disso, articular as dimensões do pensamento reflexivo crítico: o saber que é elaborado na dimensão estritamente teórica com um saber que vem de baixo e que fica, na sua maior parte, contido nas práticas. Daí a importância de resgatar, sistematizar e conceituar essas práticas. A articulação dessas dimensões possibilita a construção dialética do diálogo de saberes, indispensável à produção de um novo pensamento estratégico. Este estudo, baseado no diálogo e na construção articulada de conhecimento, resulta nas novas dimensões do desempenho daqueles que nos acostumamos a identificar como o "intelectual orgânico": não o que sabe e orienta, mas o que constrói junto com os atores-sujeitos existentes em uma sociedade concreta, desde suas realidades (RAUBER, 2004, p.23).

Há cerca de três anos, ${ }^{11}$ definíamos como nosso tema central de trabalho o estudo de práticas e formas organizacionais ensaiadas pelos movimentos sociais em diferentes contextos da América Latina, tendo como perspectiva a construção de sujeitos coletivos na práxis emancipadora. Para dar conta desse olhar para a práxis emancipadora, foi preciso revisar a definição provisória de organização que vínhamos adotando. A nova definição provisória (inspirada em DUSSEL, 2002, 2007) concebia a organização como meio para a emancipação, como atividade em que cada participante aprende a cumprir responsabilidades diferentes, sempre no espaço da unidade do consenso produzido no coletivo. Essa organização, que transforma a potência do povo em poder, efetiva-se através de processos e práticas orientados pela razão estratégico-crítica, que não é razão instrumental. Seu êxito não é o do meio-fim formal, mas o do pleno desenvolvimento da vida de todos: seu exercício realiza a ação transformadora.

Havia, naquele momento, um avanço com relação à definição que usávamos dois anos antes, quando, inspirados em Prestes Motta (1981), afirmávamos que organizar não é, necessariamente, sinônimo de organizar de modo burocrático e definíamos organizar como a ação de produzir socialmente modos de cooperação, sempre instáveis e em movimento. A definição de organização deixava de ser genérica e passava a orientar nosso olhar para um tipo de organização - a organização meio para a emancipação, práxis potencializadora, espaço de aprendizagem. Essa nova definição, provocada pela nossa experiência na pesquisa e na interação com os grupos subalternos, problematizada com o suporte teórico que buscamos nos autores aqui abordados e em outros que compartilham o mesmo projeto, encaminhou-nos, mais decididamente, para uma atividade teórica comprometida com a transformação da realidade.

No entanto, persistia certo desconforto com a nossa definição de organização. Embora dois dos autores mais presentes em nosso trabalho - Paulo Freire e Enrique Dussel - sempre se referissem à libertação, possivelmente, pelos efeitos da colonialidade do saber (LANDER, 2005), continuávamos nos referindo à emancipação. Mesmo constatando que seu uso implicava frequentes mal-entendidos, induzindo à interpretação de que nos referíamos a uma emancipação iluminada pela razão, continuávamos usando-a, ainda que muitas vezes de modo irrefletido substituíssemos "emancipação" por "libertação". Nesse contexto, encontrar o texto de Dussel, em seu último livro editado no Brasil, produziu um novo sentido.

É verdade que a revolução burguesa falava de liberdade. É necessário, agora, subsumindo-a, referirse à libertação [...]; agora, não nos referimos à liberdade, mas sim à liberta-ção como processo, como

11 Um balanço de nosso trabalho se encontra em Organização e práxis libertadora a libertação, organizado por Maria Ceci Misoczky, Rafael Kruter Flores e Joysi Moraes (2009). 
negação de um ponto de partida, como uma tensão até no ponto de chegada. Unidos aos outros postulados da revolução burguesa que enunciavam como a proclamação de "Igualdade! Fraternidade! Liberdade!", devemos transformá-los, na rebelião dos povos oprimidos e excluídos da periferia em suas lutas pela Segunda Emancipação, no novo postulado: "Alteridade! Solidariedade! Libertação!’. (DUSSEL, 2007, p.164)

A práxis da libertação tem dois momentos: uma luta negativa, desconstrutiva contra o dado, e um momento positivo de construção do novo; o vermelho quente e o vermelho frio; a denúncia e o anúncio, o pessimismo da razão e o otimismo da prática. Trata-se de uma ação que se orienta pelo princípio político crítico da factibilidade, por um possível que se coloca diante de aparentes impossibilidades práticas que precisa subverter. Práxis que exige o horizonte utópico, a esperança concreta, um projeto de transformações onde se explicitem os fins concretos da ação libertadora em todas as esferas da vida em sociedade (BLOCH, 2006; DUSSEL, 2007); práxis que exige, também e decisivamente, organiza-ção. 


\section{Referências}

ANDERSON, Ben. Transcending without transcendence: utopianism and an ethos of hope. Antipode, v.38, n.4, p.691-710, 2006.

ARAÚJO FREIRE. Inédito viável. In: STRECK, Danilo R.; REDIN, Euclides; ZITKOSKI, Jaime J. (Ed.). Dicionário Paulo Freire. Belo Horizonte: Autêntica Editora, 2008. p.231-234.

AYUSTE, Ana. Pedagogia crítica e modernidade. Pátio: revista pedagógica, v.1, n.2, p.6o-64, ago./out. 1997.

BLOCH, Ernst. O princípio esperança. Rio de Janeiro: Contraponto/Editora da Uerj, 2005. v.1.

O princípio esperança. Rio de Janeiro: Contraponto/Editora da Uerj, 2006. v.2.

CAMPIONE, Daniel. Hegemonia e contra-hegemonia na América Latina. In: COUTINHO, C. N.; TEIXEIRA, A. P. (Org.). Ler Gramsci, entender a realidade. Rio de Janeiro: Civilização Brasileira, 2003. p.51-66.

COX, Laurence; FOMINAYA, Cristina F. Movement knowledge: what do we know, ho do we create knowledge and what do we do with it? Interface, V.1, n.1, p.1-20, 2009.

DUSSEL, Enrique. Principios, mediaciones y el "bien" como síntesis (de la ética del discurso a la ética de la liberación). Signos

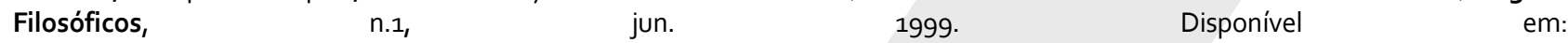
<http://redalyc.uaemex.mx/redalyc/src/inicio/ArtPdfRed.jsp?iCve=34300108\&iCveNum=5836>. Acesso em: 28 set. 2008.

Hacia una filosofía política crítica. Bilbao: Editorial Desclée de Brouwer, 2001.

Ética da libertação: na idade da globalização. Petrópolis, RJ: Editora Vozes, 2002.

20 teses de política. Buenos Aires: Clacso; São Paulo: Expressão Popular, 2007.

ERNST BLOCH e a felicidade prometida. In. ALBORNOZ, Suzana (Org.). A filosofia e a felicidade: o que os filósofos têm pensado sobre a felicidade humana. Santa Cruz do Sul: Edunisc, 2004. p.51-61.

EYERMAN, Ron; JAMISON, Andrew. Social movements: a cognitive approach. Cambridge: Polity Press, 1991.

FARIA, José Henrique. Economia política do poder. Curitiba: Juruá, 2004. 3V.

FREIRE, Paulo. Conscientização: umãteoria e prática da libertação introdução ao pensamento de Paulo Freire. São Paulo: Centauro, 1980.

Ação cultural para a liberdade. Rio de Janeiro: Editora Paz e Terra, 1984.

Pedagogia da indignação: cartas pedagógicas e outros escritos. São Paulo: Editora Unesp, 2000.

Pedagogia do oprimido. Rio de Janeiro: Editora Paz e Terra, 2005a.

Educação como prática da liberdade. Rio de Janeiro: Editora Paz e Terra, 2005b.

Pedagogia da autonomia: saberes necessários à prática educativa. Rio de Janeiro: Editora Paz e Terra, 2006.

FAUNDEZ, Antonio. Por uma pedagogia da pergunta. Rio de Janeiro: Paz e Terra, 1998.

GADOTTI, Moacir; FREIRE, Paulo; GUIMARÃES, Sérgio. Pedagogia: diálogo e conflito. São Paulo: Cortez, 1995.

GRAMSCI, Antonio. Cadernos do cárcere. Rio de Janeiro: Civilização Brasileira, 2001. v.4.

Cadernos do cárcere. 3.ed. Rio de Janeiro: Civilização Brasileira, 2002a. v.3.

Cadernos do cárcere. $3^{\mathrm{a}}$ ed. Rio de Janeiro: Civilização Brasileira, 2002b. v.5.

Cadernos do cárcere. 4.ed. Rio de Janeiro: Civilização Brasileira, 2006a. v.1. 
Cadernos do cárcere. 4.ed. Rio de Janeiro: Civilização Brasileira, 2006b. v.2.

LANDER, Edgardo (Org.) A colonialidade do saber: eurocentrismo e ciências sociais. Buenos Aires: CLACSO, 2005.

LIGUORI, Guido. Roteiros para Gramsci. Rio de Janeiro: Editora UFRJ, 2007.

LINHARES, Célia. Anúncio/denúncia. In: STRECK, Danilo R.; REDIN, Euclides; ZITKOSKI, Jaime J. (Ed.). Dicionário Paulo Freire. Belo Horizonte: Autêntica Editora, 2008. p.45-47.

LOSURDO, Domenico. Gramsci e a revolução. Tempo, v.3, n.5, p.45-73, 1998 . Disponível em <http://www.historia.uff.br/tempo/artigos_dossie/artg5-2.pdf>. Acesso em: 1 dez. 2008.

LOUREIRO, Isabel Maria. Rosa Luxemburgo: vida e obra. São Paulo: Expressão Popular, 2005.

LUXEMBURGO, Rosa. Um novo tipo de organização. In: LOUREIRO, Isabel Maria. Rosa Luxemburgo: vida e obra. São Paulo: Expressão Popular, 2005. p.47-50.

MARTÍNEZ, Víctor M. M. Pedagogía de la esperanza en una época de terrorismo. Tese de doutorado. México: Universidad la Salle, 2004. Disponível em: <http://www.cem.itesm.mx/dacs/publicaciones/logos/libros/libros/pedagogiaesp.pdf>. Acesso em: 16 set. 2008.

MEYER, Iris. Hope as the conscious action towards an open-future. In: GREEN, Rochele; HORRIGAN, Janet (Eds.) Hope: probing the boundaries. Oxford: Inter-Disciplinary Press, 2008. p.99-114

MISOCZKY, Maria Ceci; AMANTINO DE ANDRADE, Jackeline. Uma crítica à crítica domesticada nos estudos organizacionais. Revista de Administração Contemporânea, v.9, p.193-212, 2005.

FLORES, Rafael Kruter; GOULART, Sueli. Estudos organizacionais e movimentos sociais: o que sabemos? Para onde vamos? Cadernos Ebape.Br,v.6, n. 3, p.6, set. 2008.

MISOCZKY, Maria Ceci; FLORES, Rafael Kruter; MORAES, Joysi. Organização e práxis libertadora. Porto Alegre: Dacasa Editora, 2009.

MÜNSTER, Arno. Ernst Bloch: filosofia da práxis e utopia concreta. São Paulo: Editora da Unesp, 1993.

PALOS, Cássia Maria Carraco. A atualidade do pensamento de Gramsci na construção de um projeto sustentável. In: CONGRESSO PORTUGUÊS DE SOCIOLOGIA, 5., 2005, Portugal. Actas dos Ateliers.

PINTO, Álvaro Vieira. Consciência e realidade nacional. Rio de Janeiro: Iseb, 1960.

PRESTES MOTTA, Fernando C. Burocracia e autogestão: a proposta de Proudhon. São Paulo: Editora Brasiliense, 1981.

QUIJANO, Aníbal. Colonidalidad del poder, cultura y conocimiento en América Latina. In: MIGNOLO, Walter et al. (Org.). Capitalismo e geopolítica del conocimiento: el eurocentrismo y la filosofía de la liberación en el debate intelectual contemporáneo. Buenos Aires: El Signo, 2001.

RAUBER, Isabel. A transformação social en el siglo XXI: camino de reformas o de revolución. Pasado y Presente XXI, jun. 2004.

RAULET, G. Humanisation de la nature, naturalisation de I'homme: Ernst Bloch ou le projet d'une autre rationalité. Paris: Klincksieck, 1982.

TRAGTENBERG, Maurício. Sobre educação, política e sindicalismo. São Paulo: Unesp, 2004.

Administração, poder e ideologia. São Paulo: Unesp, 2005.

Burocracia e ideologia. São Paulo: Unesp, 2006.

USTARITZ, Alejandro Rojo. Utopía freireana: la construcción del inédito viable. Perfiles Educativos, n.74, oct./dic. 1996. Disponível em: <http://www.cesu.unam.mx/iresie/revistas/perfiles/perfiles/74-html/Frm.htm>. Acesso em: 24 set. 2008. 